\title{
THE FOSSIL RECORD OF GLYPTURUS STIMPSON, 1866 (CRUSTACEA, DECAPODA, AXIIDEA, CALLIANASSIDAE) REVISITED, WITH NOTES ON PALAEOECOLOGY AND PALAEOBIOGEOGRAPHY
}

\author{
by MATÚŠ HYŽNÝ ${ }^{1 *}$ and PÁL MÜLLER ${ }^{2,3}$ \\ ${ }^{1}$ Department of Geology and Paleontology, Faculty of Natural Sciences, Comenius University, Mlynská dolina G1, SK-84215 Bratislava, Slovakia; \\ e-mail: hyzny.matus@gmail.com \\ ${ }^{2}$ Magyar Állami Földtani Intézet (Geological Survey of Hungary), Stefánia út. 14, H-1143 Budapest, Hungary; e-mail: mullerp@mafi.hu \\ ${ }^{3}$ Hajnalka út. 7, H-1121 Budapest, Hungary \\ ${ }^{\star}$ Corresponding author. \\ Typescript received 10 September 2011; accepted in revised form 23 January 2012
}

Abstract: The fossil record of the callianassid genus Glypturus (Decapoda, Axiidea) is re-evaluated. Our systematic revision, both of extant and fossil taxa, is based on major cheliped morphology only, thus providing an important impetus for palaeontological studies. Both spination and tuberculation of chelipeds are herein considered of great taxonomic importance. Presence of spines on the upper margins of the merus and propodus and the lower margin of the carpus are significant for generic assignment, whereas the extent of tuberculation on lateral surfaces of the propodus is important for assignment at the species level. Altogether, four extant and six exclusively fossil species of Glypturus are recognized. Several extinct callianassid taxa are now transferred to the genus, namely Callianassa berryi, Callianassa fraasi, Callianassa munieri, Callianassa pugnax and Callianassa spinosa; Callianassa pseudofraasi is considered a junior synonym of
C. fraasi. Based on a comparison of ecological preferences of extant representatives, the presence of Glypturus in the fossil record is considered to be linked with tropical to subtropical, nearshore carbonate environments of normal salinity. We argue that Glypturus is of Tethyan origin, with a stratigraphical range going as far back as the Eocene. Since then, the genus migrated both westwards and eastwards, establishing present-day communities in the western Atlantic and IndoWest Pacific which both comprise several distinct species. In the presumed area of origin, the genus does no longer occur today. The exlusively fossil (middle Eocene) genus Eoglypturus from Italy is considered closely related to Glypturus and is thus assigned to the subfamily Callichirinae as well.

Key words: Decapoda, Callianassidae, Glypturus, Eoglypturus, palaeoecology, palaeobiogeography.
THE family Callianassidae Dana, 1852, constitutes a distinct group of fossorial shrimps that inhabit predominantly shallow intertidal and subtidal marine environments, mainly in the tropics and subtropics (Dworschak 2000, 2005). Members of this family exhibit sophisticated behaviour that involves digging complex burrow systems. Callianassids often show pronounced heterochely and in some cases also sexual dimorphism in the nature of the major cheliped, which has a great impact on interpretations of fossil material.

De Grave et al. (2009) listed 41 callianassid genera, seven of which were known as fossils only. Following their classification, the family can be subdivided into 10 subfamilies, with the great majority of named species being members of the Callianassinae Dana, 1852 and the Callichirinae Manning and Felder, 1991. However, there still is disagreement over the generic and suprageneric arrangement within the family (compare Sakai 1999, 2005, 2011 and De Grave et al. 2009). Several phylogenetic analyses, based both on morphological and molecular evidence, have been carried out in an attempt to resolve the status of the various genera (Poore 1994; Tudge et al. 2000; Felder and Robles 2009; Robles et al. 2009).

In view of the delicate nature of most of the cuticular surfaces, extinct callianassids are represented mainly by isolated chelae. Thus, the fossil material usually lacks the diagnostic characters of extant taxa, which include dorsal carapace architecture, nature of maxillipeds, form of the abdomen, pleopods, uropods and telson (for a discussion, see Schweitzer and Feldmann 2002; Schweitzer et al. 2006a). In some cases, however, these criteria can also be applied with some certainty to the fossil record (e.g. Schweitzer-Hopkins and Feldmann 1997; Schweitzer and 
Feldmann 2002), notably when the features essential for generic assignment occur on chelipeds (see Manning and Felder 1991). The genus Glypturus Stimpson, 1866 is such a case, and here we re-examine several fossil taxa with respect to extant ones.

\section{MATERIAL}

The material studied can be divided into two sets: specimens examined personally by at least one of us and material unseen but checked carefully according to pertinent items of literature (illustrations and descriptions) and/or additional photographs supplied to us. Details of all specimens studied are supplied under each taxon in the systematic section later. Parameters measured are the same as in the study of Hyžný and Schlögl (2011, text-fig. 3).

Institutional abbreviations. The repositories of specimens illustrated or referred to later are as follows: BMNPH PI IC, Department of Palaeontology, The Natural History Museum, London, UK; E, Hungarian Geological Survey (Magyar Állami Földtani Intézet), Budapest, Hungary; KGP-MH, Department of Geology and Paleontology, Comenius University, Bratislava, Slovakia; M (old acquisitions) or PAL (acquisitions since 2011), Hungarian Natural History Museum, Budapest, Hungary; MB.A, Museum für Naturkunde, Leibniz-Institut für Evolutions- und Biodiversitätsforschung, Humboldt-Universität, Berlin, Germany; MCZ, Museo Civico 'G. Zannato', Montecchio Maggiore, Vicenza, Italy; MNHN.F, Collection de Paléontologie, Muséum national d'Histoire naturelle, Paris, France; NHMW, Naturhistorisches Museum Wien, Vienna, Austria; NMCR, National Museum of the Philippines, Manila, the Philippines; USNM, United States National Museum (Smithsonian Institution), Washington DC, USA.

\section{SYSTEMATIC PALAEONTOLOGY}

Remarks. Higher-rank classification follows De Grave et al. (2009).

\section{Order DECAPODA Latreille, 1802 Infraorder AXIIDEA de Saint Laurent, 1979 \\ Family CALLIANASSIDAE Dana, 1852}

Remarks. There is an extensive fossil record of Callianassidae from around the world, but most of the material has not yet been restudied with respect to modern classification. As a result of ongoing research of extinct callianassids using biological and palaeontological criteria for generic assignment, it is now possible to determine the placement of numerous fossil specimens, previously referred to as 'Callianassa' (e.g. Müller 1984a), more precisely. As already noted, fossil remains of Callianassidae are often represented exclusively by isolated chelae, making generic assignment very difficult. Moreover, occasionally ctenochelid genera, notably Gourretia de Saint Laurent, 1973 and Callianopsis de Saint Laurent, 1973, can easily be misinterpreted as callianassids when dealing with cheliped fragments only. This actually happened in the case of Gourretia aquilae (Rathbun, 1935) and several species of Callianopsis; for a more detailed discussion of this issue, reference is made to Hyžný and Schlögl (2011, p. 325).

\section{Subfamily CALLICHIRINAE Manning and Felder, 1991}

Remarks. The original diagnosis (Manning and Felder 1991, p. 775) is rather short and based on characters which usually are absent in the fossil record: dorsal carapace, maxillipeds and pleopods. The definition proposed by Sakai (2005, p. 120) is more detailed, but mostly fails to assist palaeontologists in interpreting their material. For instance, with regard to chelipeds, his definition (Sakai 2005, p. 210) states, 'P1 chelate, unequal or subequal, and similar or dissimilar; larger cheliped with or without meral hook'. However, much the same can be said of the Callianassinae (see Sakai 2005, p. 11). Without having diagnostic characters of maxillipeds and pleopods, assignment of fossil species to subfamilies is virtually impossible. When dealing with fossils, the subfamilial assignment depends on the identification of specimens as members of extant genera. Therefore, several exclusively fossil callianassid genera cannot be assigned to any subfamily (see e.g. De Grave et al. 2009, p. 22).

The fossil record of the Callichirinae is fairly extensive, although the majority of species studied have been assigned to Neocallichirus Sakai, 1988. According to De Grave et al. (2009) and Schweitzer et al. (2010), some 39 species in nine genera of the Callichirinae have been described from the fossil record. Since then, three additional species have been erected, namely Callichirus bertalani Hyžný and Müller, 2010, Neocallichirus hattai Karasawa and Nakagawa, 2010 and Neocallichirus agadirensis Garassino, De Angeli and Pasini, 2011. It should be noted that a recent molecular study (Felder and Robles 2009) failed to resolve the subfamily Callichirinae in its present arrangement as a monophyletic grouping.

Hyžný and Müller (2010) have recently reviewed the fossil record of Callichirus, providing also a diagnosis of the genus based on hard-part morphology. Currently, the genus Corallianassa Manning, 1987 is known from three fossil taxa (De Angeli and Garassino 2006), while there is but a single fossil record of Lepidophthalmus Holmes, 1904 (see Collins et al. 2009) and of Michaelcallianassa 
Sakai, 2002, no extinct taxa are known. Assignment of Grynaminna Poore, 2000, Neocallichirus, Podocallichirus Sakai, 1999 and Sergio Manning and Lemaitre, 1994 deserves special attention. These four genera are virtually indistinguishable from one another when considering only chelipeds. Unfortunately, numerous fossil species have been assigned to Neocallichirus (i.e. Schweitzer et al. 2010 list 18), whose diagnosis, based exclusively on hard parts, is rather wide (Manning 1993, p. 108; Sakai 2005, p. 160). Differences in hard-part morphology of taxonomic importance in Grynaminna, Neocallichirus, Podocallichirus and Sergio and implications for the fossil record have recently been outlined by Hyžný and Karasawa (2012). The present study focuses on the systematics and fossil record of the genus Glypturus.

\section{Genus GLYPTURUS Stimpson, 1866}

Type species. Glypturus acanthochirus Stimpson, 1866, by monotypy.

Included species. See Table 1.

Diagnosis. Reference is made to Manning (1987, p. 390) and Manning and Felder (1991, p. 778).

General remarks. The genus was erected by Stimpson (1866) and redefined by Manning (1987), who distinguished it definitively from Callianassa Leach, 1814 and provided a proper diagnosis. The primary features are a sharp, upturned rostral spine; anterolateral spines of the carapace are separated from the carapace by a noncalcified membrane, and claw ornament, with dorsal spines on both meri and propodi of chelipeds.

Manning (1987) synonymized Callianassa armata A. Milne-Edwards, 1870 with G. acanthochirus and listed sev- eral different species that were possibly attributable to Glypturus, although he hesitated to re-assign any of them without proper re-examination of the type material. Amongst those species, he mentioned also Callichirus laurae de Saint Laurent in de Vaugelas and de Saint Laurent, 1984 and noted that it shared with G. acanthochirus a tuberculate palm. Later, Poore and Suchanek (1988) disagreed with the synonymization of C. armata with G. acanthochirus, recognizing them as separate species of Glypturus, together with C. laurae, and adding a new one, G. motupore Poore and Suchanek, 1988. Manning and Felder (1991) concurred with Poore and Suchanek (1988) in accepting four species of Glypturus, all of them possessing a distinctly spiny merus, carpus and propodus. Sakai (1988) omitted spines on chelipeds as one of the diagnostic features of Glypturus. Instead, he presented a rather wide diagnosis of the genus and listed the following species for Australia: Callianassa collaroy Poore and Griffin, 1979, C. martensi Miers, 1884 (= C. haswelli Poore and Griffin, 1979), C. mucronata Strahl, 1861 and C. karumba Poore and Griffin, 1979. Later (Sakai 1999, 2005), he relegated Corallianassa Manning, 1987 and Corallichirus Manning, 1992 into the synonymy of Glypturus, an action criticized by several authors (Ngoc-Ho 2005; Dworschak 2007). Finally, he recognized some 15 species as members of Glypturus (Sakai 2005, p. 132) and also (Sakai 1999, 2005) transferred G. motupore to the genus Neocallichirus (!) and synonymized C. laurae with C. armata. The shape of the telson in larval stages of C. laurae and C. armata, however, speaks for their specific distinction (Seridji 1995). Sakai (2011) maintained the synonymy of Corallianassa with Glypturus and listed 13 species for this 'wider' genus, yet did recognize Corallichirus as valid with three species, based upon differences in male first and second pleopods.

Tudge et al. (2000) listed seven species of Glypturus, viz. G. acanthochirus, G. armatus, G. karumba, G. laurae,

TABLE 1. Synopsis of species of Glypturus known to date.

\begin{tabular}{|c|c|c|}
\hline $\begin{array}{l}\text { Species with an exclusively } \\
\text { G. laurae } \\
\text { G. sp. (= G. rabalaisae s }\end{array}$ & men nudum) & \\
\hline \multicolumn{3}{|c|}{ Extant species known also from the fossil record } \\
\hline G. armatus & Pliocene & Vanuatu \\
\hline G. acanthochirus & Late Pleistocene & Jamaica \\
\hline \multicolumn{3}{|l|}{ Exclusively fossil species } \\
\hline G. fraasi comb. nov. & Middle-late Eocene & Egypt, Spain, Hungary, ?Namibia \\
\hline G. spinosus comb. nov. & Late Eocene & Hungary \\
\hline G. berryi comb. nov. & Oligocene & USA (Mississippi) \\
\hline G. munieri comb. nov. & Middle-late Miocene & Hungary, Austria, Malta \\
\hline G. toulai & Late Miocene & Panama \\
\hline G. pugnax comb. nov. & Late Miocene & Java \\
\hline
\end{tabular}

Note: data on stratigraphical age and geographical distribution are supplied only for fossil taxa. Reference is made to the text for details of geographical distribution of exclusively extant forms. 
G. martensi, G. motupore and G. mucronata. Interestingly, results presented by those authors favoured a paraphyletic or even polyphyletic nature for Glypturus in such an arrangement. This is not surprising, as C. martensi, C. karumba and C. mucronata lack distinct spines on chelipeds and are very different in other respects from species of Glypturus (sensu Manning 1987).

Herein, we follow the diagnosis provided by Manning (1987), in support of Manning and Felder (1991), Poore (1994) and Ngoc-Ho (2005). We agree that the spinulous character of the chelipeds is typical of Glypturus; usually, there are three spines on the upper margin of the propodus and spines on lower margins of the carpus, merus and ischium. As a conclusion, we argue that the genus can be distinguished from others on the basis of chelipeds only and accept as valid four extant species, viz. Glypturus acanthochirus, G. armatus, G. laurae and G. sp. (= G. rabalaisae sensu Sakai 2005, 2011; name unavailable). We consider G. motupore to be a junior synonym of G. armatus.

In several callianassid and ctenochelid genera and species, cheliped morphology is an expression of sexual dimorphism. Thus, this may be of use to palaeontologists who have no other means of determining sex in the fossil material. Unfortunately, no sexual dimorphism in chelipeds of Glypturus has been observed to date (e.g. Biffar 1971; Poore and Suchanek 1988).

Spination and tuberculation of chelipeds. The systematic value of cheliped characters, notably 'dentition and spination' was already mentioned by Biffar (1971, p. 642). This is very useful for palaeontologists when generally only chelipeds are available. As to tuberculation, this is a more variable feature which does not occur in all species. However, when present, it has taxonomic potential for specific identification. Here, we use the term 'tuberculation', rather than 'granulation', although there is no strict consensus in the usage of either term.

As Manning (1987) stated in his diagnosis of Glypturus, three spines on the upper margin of propodus are typical of the genus. They are arranged distally, which means that the position of the proximalmost spine is not beyond two-thirds of propodus length. Spines are usually oriented under a distally directed angle. Interestingly, some variability in spine arrangement and also number can be seen. Biffar (1971) noted in his diagnosis and description of Callianassa acanthochirus that there were two or three spines on the upper margin of the propodus. One specimen of G. acanthochirus examined for the present study (NHMW 24967) has five spines on the upper margin of the major cheliped (Fig. 2A-C) and four on the minor. Similarly, one specimen of Glypturus sp. (= G. rabalaisae sensu Sakai 2005, 2011), described and illustrated by Rabalais et al. (1981, text-fig. 3D, E) as G. acanthochirus, exhibits four spines. In the description of Callianassa fraasi, Noetling (1885) recorded variation between two and four spines. In this respect, it should be noted that the distalmost spine may occasionally be positioned more mesially (i.e. pointing inwards) than the other more proximal spines, which means that it can be overlooked when not fully exposed. This may happen especially when working with poorly preserved fossil material. Notable examples include the case of Callianassa pseudofraasi and, possibly, Noetling's (1885, p. 492) description of Callianassa fraasi.

Spination of the carpus, merus and ischium also is a rather variable feature, although its presence is significant for generic assignment. In Glypturus, the number of spines on the lower margin of the carpus usually varies between six and 10. Spines typically point downwards and distally. It is worth mentioning that in some cases the spination on the lower margin of the carpus may be partially interrupted, as documented in a specimen of G. laurae (Fig. 3J). The upper margin of the carpus does not possess any spines.

On the merus, there are several ornament characters: spines on both lower and upper margins, presence of a longitudinal keel on the outer surface, dividing the merus into two halves (see Fig. 1A), and tuberculation in its lower half. On the upper margin, there usually are three spines; however, examples with two (e.g. Glypturus armatus, Fig. 1H; see also Rabalais et al. 1981, fig. 3E) and four spines (G. armatus, Fig. 1G) are also known. Rabalais et al. (1981, p.104) also recorded a single specimen of G. acanthochirus (= G. rabalaisae sensu Sakai 2005, 2011) with only one spine. Poore and Suchanek (1988) noted the presence of up to eight spines on the upper margin of the merus in G. motupore. In general, the most distally positioned upper meral spine may be situated slightly mesially. Spination of the meral lower margin usually is strongly developed; however, both the number of spines and spacing between individual spines vary both intra- and interspecifically. Most proximal spines usually are not aligned with the others; they originate above other spines on the lateral surface, at the position of the meral keel (Fig. 3G$\mathrm{J})$. Usually, only one spine is found in this position; however,

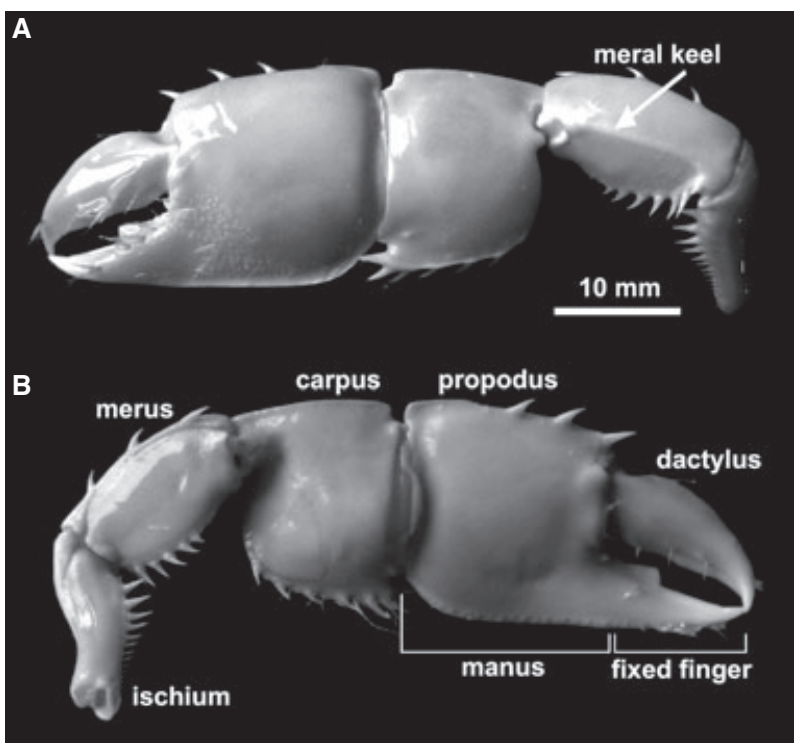

FIG. 1. Basic morphology of the major cheliped of Glypturus acanthochirus Stimpson, 1866 (NHMW 15342), with terminology used in the text, in outer (A) and inner (B) views. Note spination of the upper margins of the merus and propodus and of the lower margins of the ischium, merus and carpus. 
two spines (Fig. 3J), or none at all, may also be observed (Fig. 3D).

The development of the meral longitudinal keel appears to be related to the development of tuberculation in the lower half of the meral lateral face. In species (or individuals) that lack tuberculation, the keel is very weakly developed and in strongly tuberculate species (or individuals) it is pronounced (Fig. 3D-J).

When dealing with chelipeds only, species of Glypturus can be distinguished from each other by the nature of the major chelae, especially with regard to tuberculation of the lateral surface of the propodus (Fig. 4). As demonstrated here, this criterion works for both extant and fossil material. It should be noted that tuberculation may also be subject to some variation depending upon the age and size of the animal. For instance, Poore and Suchanek (1988) examined 10 specimens of G. motupore with chelipeds, and all except one possessed lateral surfaces of the propodi without tubercles (Poore and Suchanek 1988, p. 202). Unfortunately, they did not mention whether the tuberculate specimen was exceptionally large or not, as it seems that larger specimens usually possess more prominent tubercles. More pronounced tuberculation in large specimens, as compared to smaller individuals, has also been observed in several callichirine species (P. C. Dworschak, pers. comm. 2010). Concerning the level of variation, it seems that tuberculation of the outer lateral surface is more consistent within the species and that on the inner is more variable (e.g. G. munieri). Occasionally, tuberculation is missing (e.g. G. acanthochirus; P. C. Dworschak, pers. comm. 2010).

It should be noted that cheliped spination also occurs in several other members of the Callianassidae. However, it never attains such arrangement and expression as in Glypturus. For instance, in Lepidophthalmus grandidieri (Coutière, 1899), spines are present distally both on upper and lower margins of the carpus, but confined only to the points of articulation with the propodus. A similar arrangement of spines was also recorded for Eucalliax quadracuta (Biffar, 1970) and E. panglaoensis Dworschak, 2006. Eucalliax quadracuta also possesses several tiny spines with larger ones positioned distally on the upper margin of the major propodus (Biffar 1970, p. 42; M. H., pers. obs.). It should be noted that in both Lepidophthalmus and Eucalliax, carpal spines do not occur in all species, and propodal spination has been noted for E. quadracuta only. Spination of the entire lower margin of the carpus occurs exclusively in species of Glypturus. In contrast, armature and tuberculation of the merus are quite common in many genera of the Callichirinae. However, the presence of several large spines along the entire lower margin is unique for Glypturus.

In addition to the fossil species that can clearly be assigned to Glypturus, there are several reports of Callianassidae which are worth mentioning here because of their broad resemblance to the genus studied.

Rathbun (1919) described a new species, Callianassa anguillensis, from the Miocene of Anguilla on the basis of several fragmentary specimens. The holotype (USNM MO 166941) is an incomplete propodus (Rathbun 1919, pl. 1, fig. 1); its tuberculation is much the same as the one seen in typical Glypturus as discussed earlier. The upper margin is insufficiently preserved to determine the number of expected spines; Rathbun (1919, p. 164), however, in the description of the holotype, stated that,
' $\ldots$ the surface thus exposed is blunt and transversely rugose, and on the inner side just below the (upper) margin and $3.7 \mathrm{~mm}$ from the distal end there is a curved tubercle, pointing forward; also in the same line a spine at the distal extremity'. Without re-examination of this material and lacking indications of the number of presumed propodal spines, we are at present hesitant to attribute this species to Glypturus.

Schweitzer et al. (2006a) noted the presence of several indeterminate callianassid species in the Bateque and Tepetate formations (Eocene) of Mexico. Their Callianassidae sensu lato species 2 (Schweitzer et al. 2006a, fig. 3.2) resembles Glypturus in several respects. The fixed finger has a large, oblong tooth on its occlusal surface. Most importantly, it possesses scattered tubercles on the lateral surface of the propodus near the base of the fixed finger arranged in a manner very similar to that of Glypturus. The upper margin of the propodus was described as very slightly convex and finely serrated; no spines, however, were noted.

Schweitzer et al. (2006b) described a new species, Neocallichirus? quisquellanus, from the Miocene of the Dominican Republic on the basis of a single specimen, a right major propodus with pronounced tuberculation on its outer surface resembling that of Glypturus. General propodus shape is also quite similar to Glypturus, but no spines on the upper margin were reported. The specimen was illustrated in matrix (Schweitzer et al. 2006b, fig. 3D), which means that the presence of still covered spines cannot be ruled out. Schweitzer et al. (2006b) noted that the specimen was unlike many species of Neocallichirus, which is why it was assigned to Neocallichirus with a query. Note, however, that in Schweitzer et al. (2010, p. 39), it is listed without a question mark.

Stratigraphic range. Middle Eocene to Holocene. Prior to the present study, the oldest fossil occurrence of the genus was Miocene (Glypturus toulai; see Todd and Collins 2005). Other occurrences included Callianassa armata from the Pliocene (Abrard 1947) and G. acanthochirus from the Pleistocene (Collins et al. 1996); both taxa also are extant.

\section{EXTANT SPECIES}

\section{Glypturus acanthochirus Stimpson, 1866 Figures $1 \mathrm{~A}-\mathrm{B}, 2 \mathrm{~A}-\mathrm{C}, 3 \mathrm{~A}-\mathrm{C}, \mathrm{I}, 4 \mathrm{C}$}

\footnotetext{
${ }^{\star} 1866$ Glypturus acanthochirus Stimpson, p. 46.

1871 Glypturus acanthochirus Stimpson; Stimpson, p. 121.

1899 Glypturus acanthochirus Stimpson; Kingsley, p. 821.

1900 Glypturus acanthochirus Stimpson; Rathbun, p. 150.

1901 Glypturus acanthochirus Stimpson; Rathbun, p. 93.

1903 Glypturus acanthochirus Stimpson; Borradaile, p. 548.

1928 Glypturus acanthochirus Stimpson; de Man, p. 19, 25, 180.

1935 Callianassa (Callichirus) acanthochirus (Stimpson); Schmitt, p. 20, pl. 1, fig. 6; pl. 2, fig. 5; pl. 3, figs 4, 6 .

1943 Callianassa acanthochirus (Stimpson); Gurney, p. 84.

1971 Callianassa acanthochirus (Stimpson); Biffar, p. 655, figs 3-4.

1979 Callichirus acanthochirus (Stimpson); de Saint Laurent and Le Loeuff, p. 96.
} 

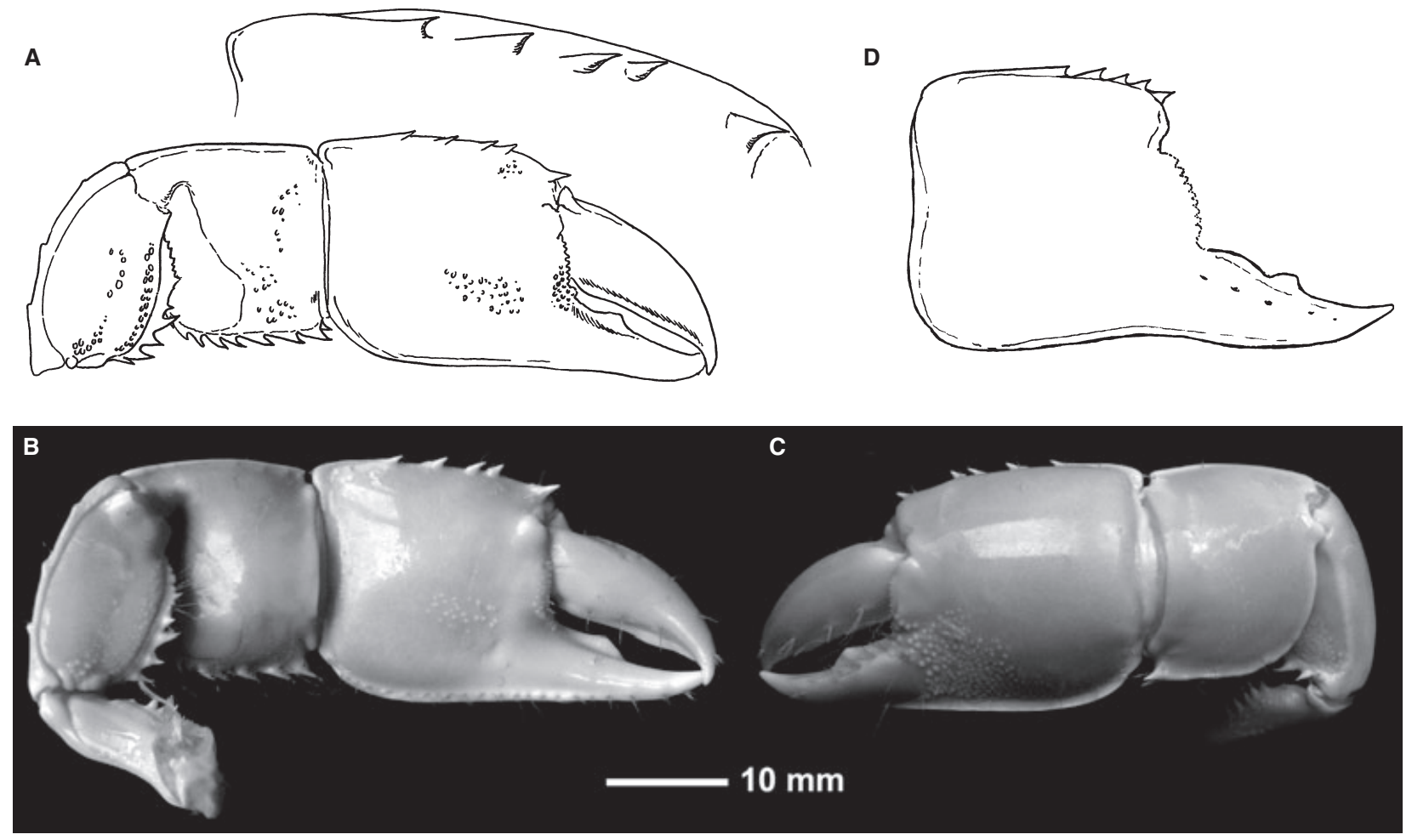

FIG. 2. Propodal spination in Glypturus and Eoglypturus. A-C, Glypturus acanthochirus Stimpson, 1866 (NHMW 24967), major cheliped in inner (A-B) and outer (C) views, with five propodal spines. D, Reconstructed appearance of the propodus of Eoglypturus grolensis Beschin, De Angeli, Checchi and Zarantonello, 2005 (after Beschin et al. 2005) with five spines (length of the element is approximately $2 \mathrm{~cm}$ ). Spines are in a position that differs from that usually seen in Glypturus.

1987 Glypturus acanthochirus Stimpson; Manning, p. 390, fig. 3.

1988 Glypturus acanthochirus Stimpson; Poore and Suchanek, p. 201, fig. 4d.

1991 Glypturus acanthochirus Stimpson; Manning and Felder, p. 778.

1992 Glypturus acanthochirus Stimpson; Dworschak, p. 209.

1993 Glypturus acanthochirus Stimpson; Dworschak and Ott, p. 282.

1996 Glypturus acanthochirus Stimpson; Collins et al., p. 54, pl. 12, fig. 1; pl. 15, figs 1, 3, 4.

1999 Glypturus acanthochirus Stimpson; Sakai, p. 73, fig. 14i.

2000 Glypturus acanthochirus Stimpson; Tudge et al., p. 144.

2003 Glypturus acanthochirus Stimpson; Curran and Martin, pp. 230, 234, fig. 4B.

2004 Glypturus acanthochirus Stimpson; Dworschak, p. 20, fig. $4 \mathrm{~F}$.

2005 Glypturus acanthochirus Stimpson; Sakai, p. 133.

2005 Glypturus acanthochirus Stimpson; Abed-Navandi and Dworschak, p. 160.

2009 Glypturus acanthochirus Stimpson; Collins et al., p. 70.

2009 Glypturus acanthochirus Stimpson; Felder et al., p. 1062.

2011 Glypturus acanthochirus Stimpson; Sakai, p. 431, fig. $65 \mathrm{~A}, \mathrm{~B}$.
Material. NHMW 6770 (Fig. 3A), NHMW 15338, NHMW 15342 (Fig. 3G), NHMW 24967 (Fig. 2A-C), NHMW 24968 (Fig. 3B-C).

Occurrence. To date, this species is known from the western Atlantic (Atlantic coast of Florida, Gulf of Mexico, entire Caribbean, plus Caribbean coast of Colombia and Venezuela; see Dworschak 1992; Sakai 2005; Felder et al. 2009). Fossil representatives have been recorded from the upper Pleistocene Port Morant Formation of Jamaica by Collins et al. (1996).

Diagnosis. See Biffar (1971, p. 655).

Remarks. Glypturus acanthochirus is a well-known species. With regard to hard-part morphology, it can be distinguished from congeners on the basis of tuberculation on the lateral surfaces of the propodus (Fig. 4). Propodal tuberculation as a relatively consistent distinguishing feature was previously mentioned by Biffar (1971, p. 660) and Manning (1987, p. 392); the former author compared 'tuberculated' G. acanthochirus to 'smooth' G. armatus.

Of all extant species, G. acanthochirus has the comparatively most robust chelipeds. Tuberculation on the propodus is rather coarse and prominent; the same goes for the carpus (in part), merus and ischium. The merus is deep 

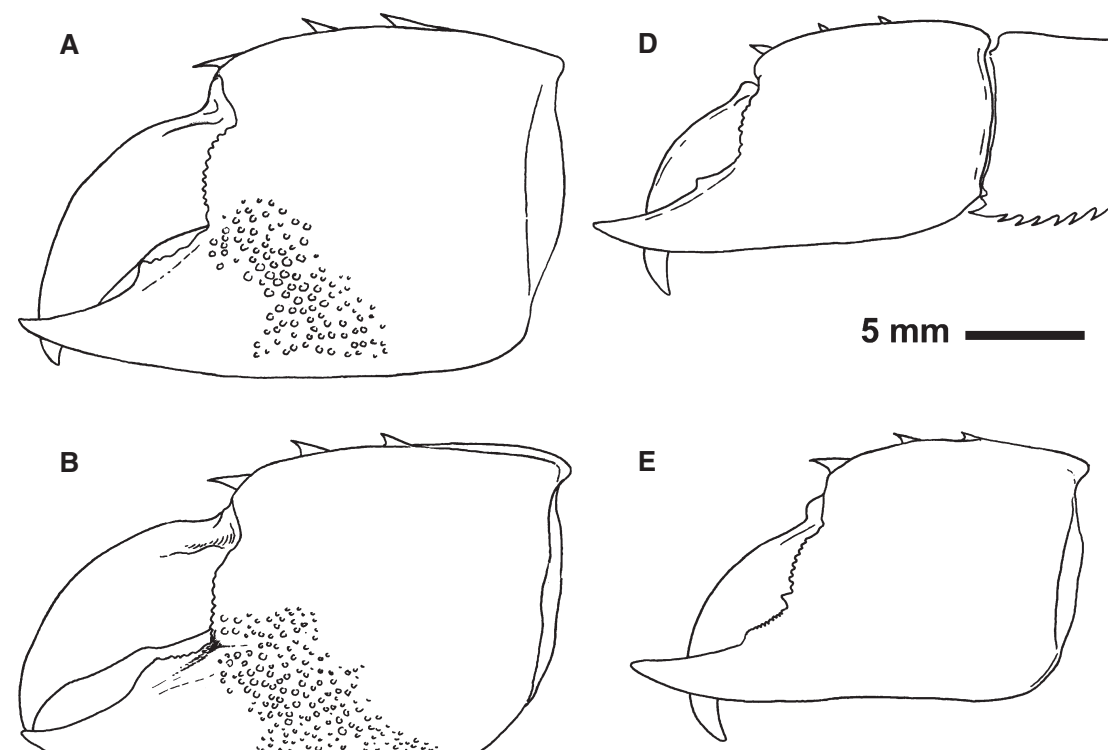

G
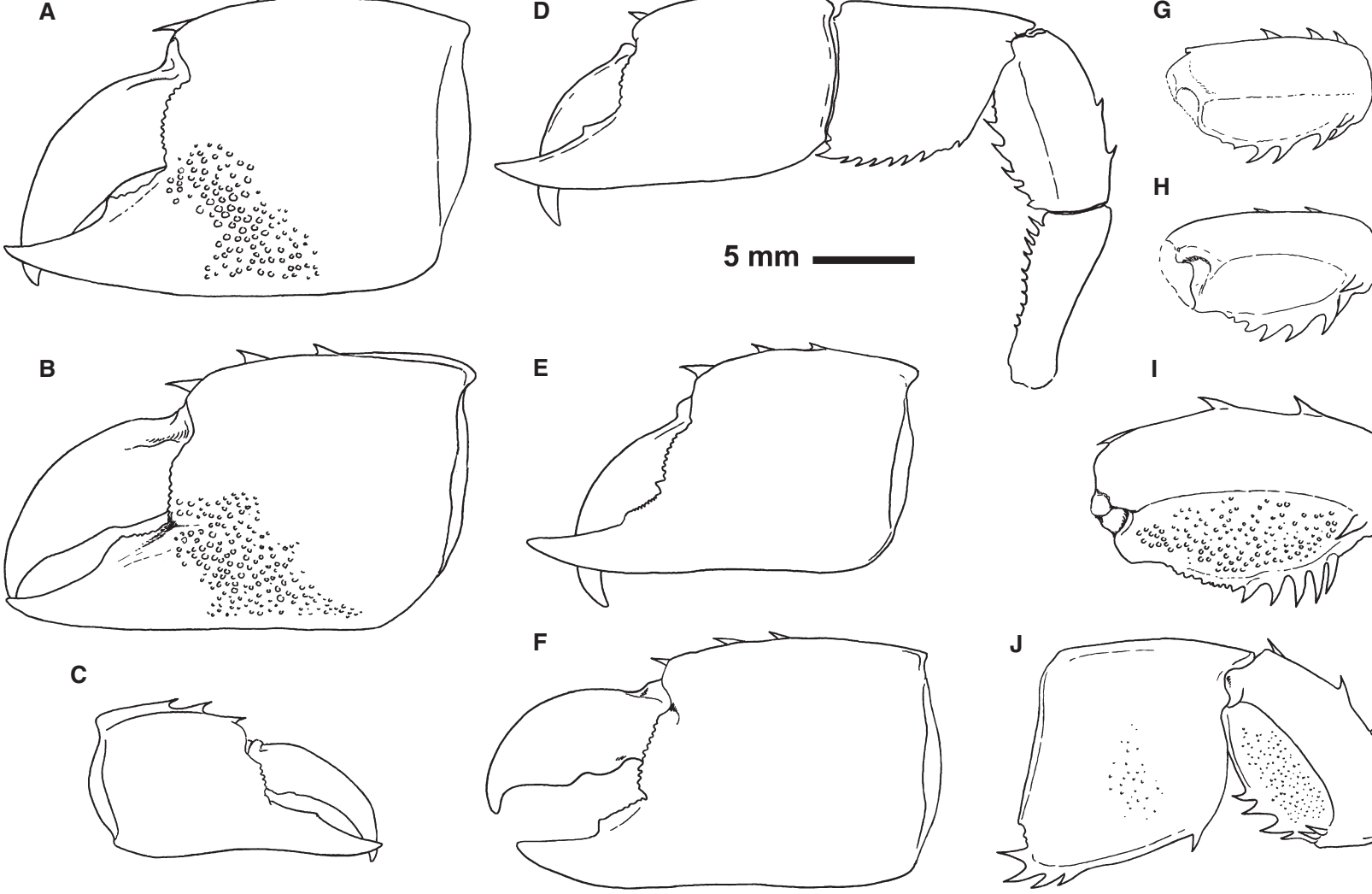

H
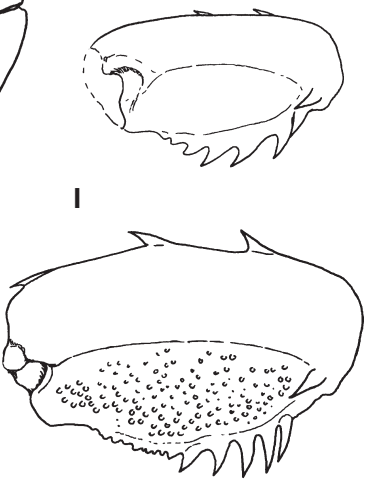

C
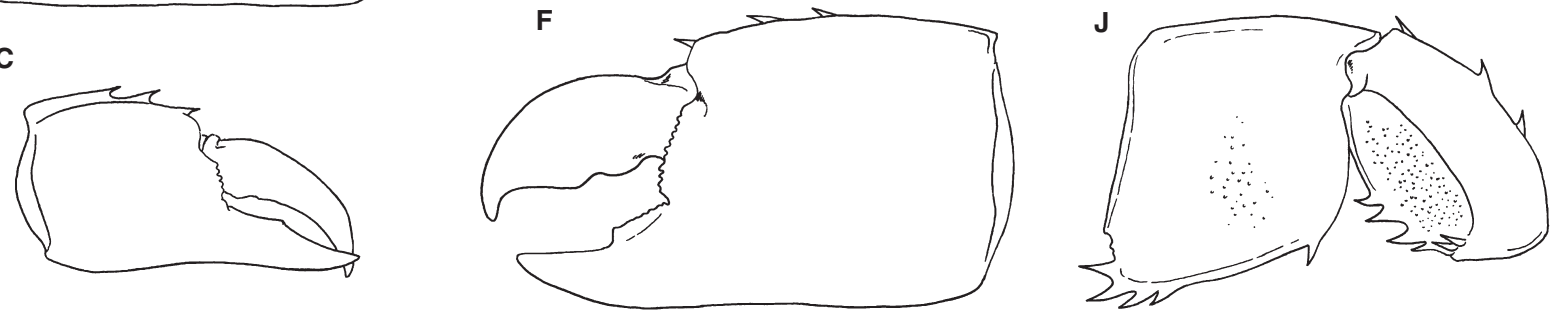

FIG. 3. Extant species of Glypturus. A, G. acanthochirus Stimpson, 1866, NHMW 6770 (major), left propodus and dactylus. B, G. acanthochirus Stimpson, 1866, NHMW 24968 (major), left propodus and dactylus. C, G. acanthochirus Stimpson, 1866, NHMW 24968 (minor), right propodus and dactylus; note pronounced keel on the upper margin of the propodus. D, G. armatus (A. MilneEdwards, 1870), NHMW 23822 (major), left cheliped. E, G. armatus (A. Milne-Edwards, 1870), NHMW 21941 (major), left propodus and dactylus. F, G. armatus (A. Milne-Edwards, 1870), NMCR 39031 (major), left propodus and dactylus. G, G. armatus (A. MilneEdwards, 1870), NHMW 21941 (major), left merus. H, G. armatus (A. Milne-Edwards, 1870), NMCR 39031 (major), left merus. I, G. acanthochirus Stimpson, 1866, NHMW 15342 (major), left merus. J, G. laurae (de Saint Laurent in de Vaugelas and de Saint Laurent, 1984), NHMW 6973 (major), left merus and carpus; note missing spines on the lower margin of the carpus. In all figures, setae are omitted. All figures to the same scale.

and bears a pronounced keel on the lateral surface (Figs 1A and 3J); tuberculation of the lower half usually is well developed (Fig. 3J).

The tuberculate area on the outer lateral surface of the propodus extends from the base of the fixed finger and extends diagonally to the lower margin (Fig. 4C); it does not extend to the proximal lower corner as in Glypturus berryi comb. nov. (Fig. 4E) and G. fraasi comb. nov. (Fig. 4F). Tuberculation on the inner lateral surface extends to a lesser extent, and tubercles are not as closely spaced as on the outer surface (Fig. 4C). Not all specimens possess tuberculation on the inner surface, because its extent and development depend more or less of size and/or age of the specimen (P. C. Dworschak, pers. comm. 2010). The general pattern of tuberculation on the outer surface is, however, quite consistent within the species.
Glypturus armatus (A. Milne-Edwards, 1870) Figures 3D-H, 4A, 5A-D

${ }^{\star} 1870$ Callianassa armata A. Milne-Edwards, pp. 90, 101, pl. 1.

1902 Callianassa armata A. Milne-Edwards; de Man, p. 754.

1903 Callianassa (Callichirus) armata A. Milne-Edwards; Borradaile, p. 547.

1928 Callianassa (Callichirus) armata A. Milne-Edwards; de Man, pp. 28, 93, 109.

1947 Callianassa armata A. Milne-Edwards; Abrard, p. 92, pl. 5, figs $42-43$.

1975 Callianassa armata A. Milne-Edwards; Kensley, p. 48, fig. $1 \mathrm{~A}-\mathrm{H}$.

1987 Callianassa armata A. Milne-Edwards; Manning, pp. 390, 392.

1987 Glypturus acanthochirus Stimpson; Manning, p. 390, figs 4-5 (partim). 


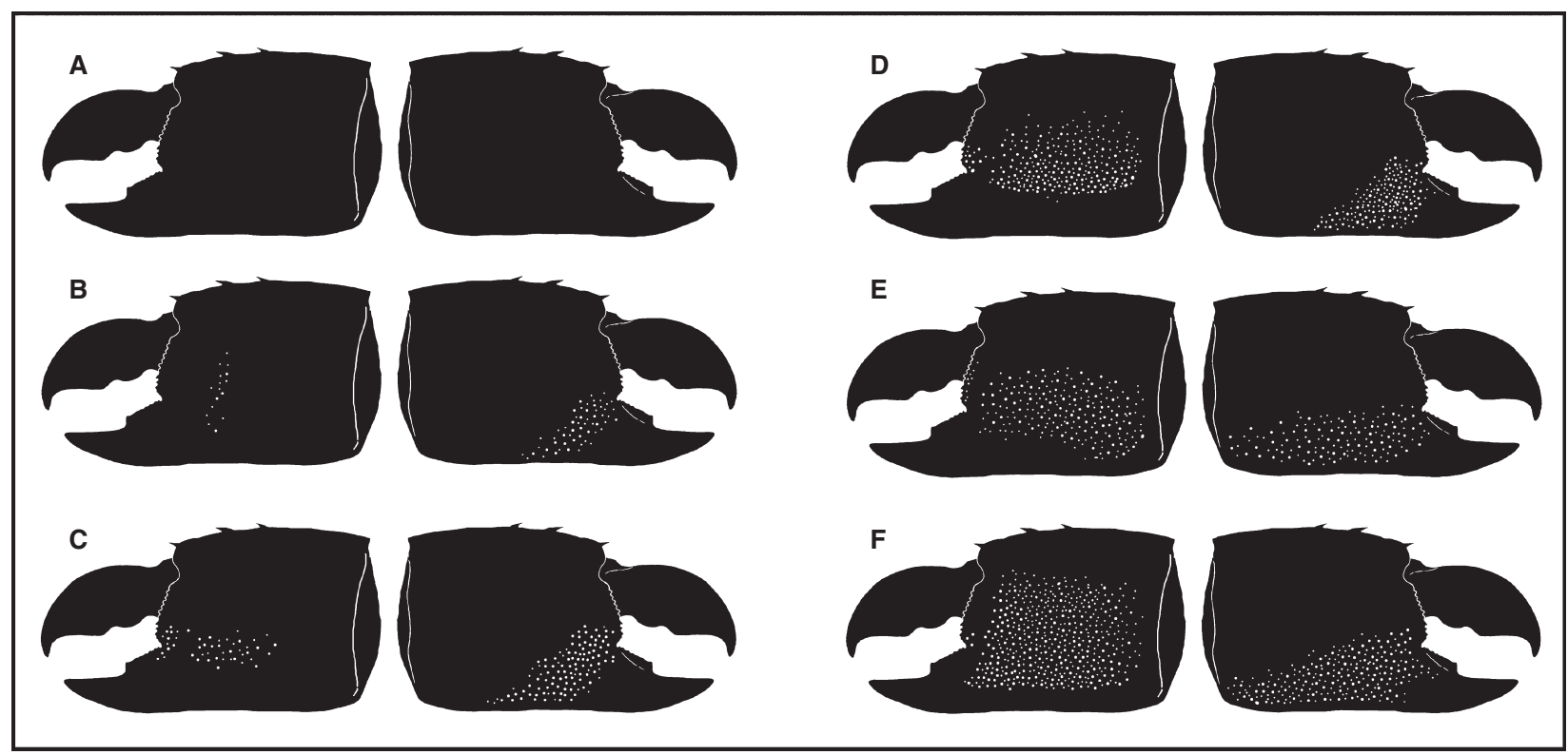

FIG. 4. Scheme of tuberculation on the major propodus in Glypturus (not to scale). A, G. armatus (A. Milne-Edwards, 1870) (based on NHMW 21941). B, G. laurae (de Saint Laurent in de Vaugelas and de Saint Laurent, 1984) (based on NHMW 6973). C, G. acanthochirus Stimpson, 1866 (based on NHMW 15338). D, G. munieri (Brocchi, 1883) comb. nov. (based on M.86.309, see also Fig. 8D-H). E, G. berryi (Rathbun, 1935) comb. nov. (based on USNM MO 495112, holotype). F, G. fraasi (Noetling, 1885) comb. nov. (based on Vía Boada 1969). Left column - inner surface; right column - outer surface.

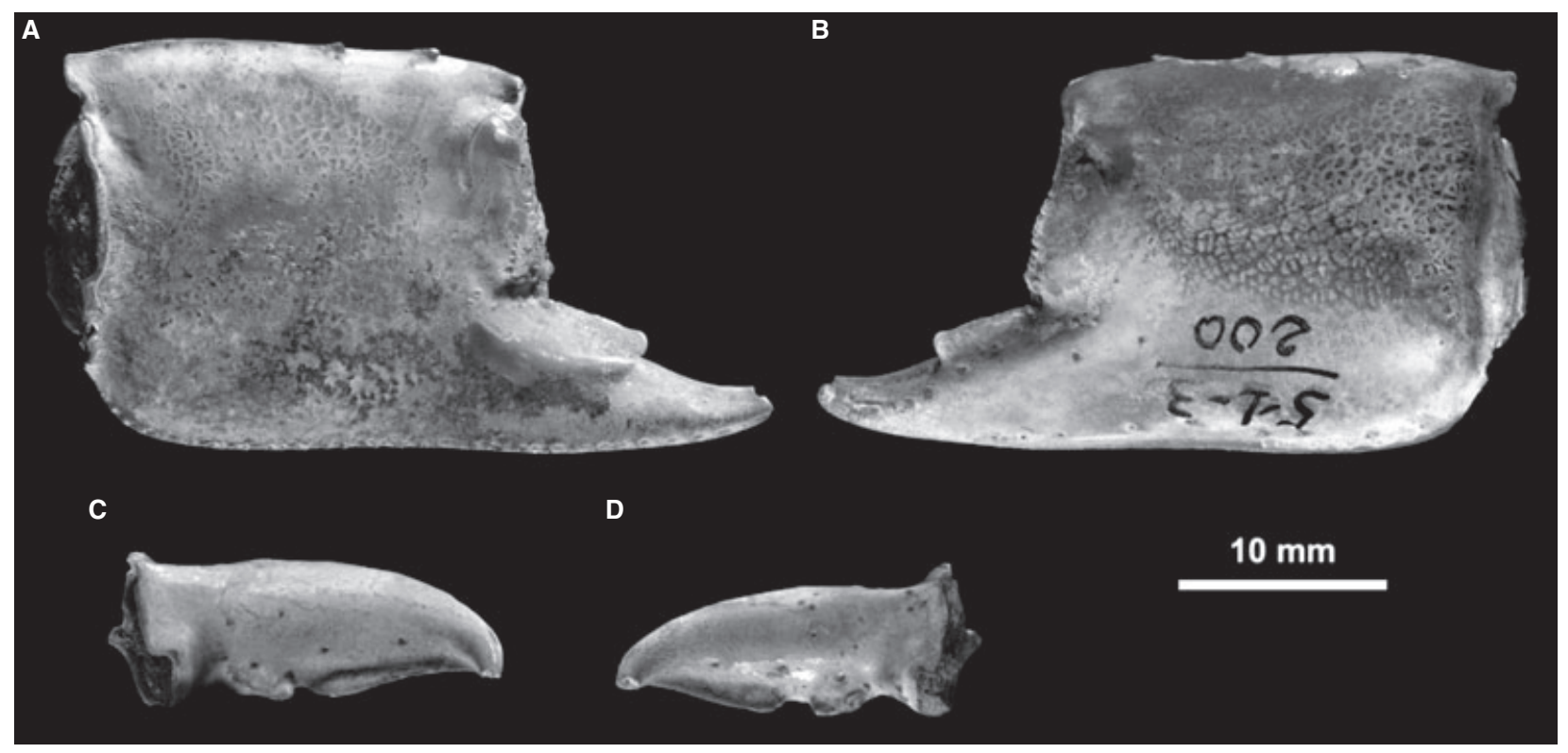

FIG. 5. Glypturus armatus (A. Milne-Edwards, 1870). A-B, left major propodus in inner and outer views, respectively. C, left major dactylus. D, right major dactylus. All materials (MNHN.F A27009, Aubert de la Rüe Collection) from the Pliocene of Vanuatu (Abrard 1947). All figures to the same scale.

1988 Glypturus motupore Poore and Suchanek, p. 198, figs $1-3,4 a$.

1988 Glypturus armatus (A. Milne-Edwards); Poore and Suchanek, p. 201.

1991 Glypturus armatus (A. Milne-Edwards); Manning and Felder, p. 778.
1991 Glypturus motupore Poore and Suchanek; Manning and Felder, p. 778.

1999 Glypturus armatus (A. Milne-Edwards); Sakai, p. 76 (partim).

1999 Neocallichirus motupore (Poore and Suchanek); Sakai, p. 105. 
2000 Glypturus armatus (A. Milne-Edwards); Tudge et al., p. 144.

2000 Glypturus motupore Poore and Suchanek; Tudge et al., p. 144.

2005 Glypturus armatus (A. Milne-Edwards); Sakai, p. 137 (partim).

2005 Neocallichirus motupore (Poore and Suchanek); Sakai, p. 182.

2007 Glypturus armatus (A. Milne-Edwards); Anker and Dworschak, p. 290.

2011 Glypturus armatus (A. Milne-Edwards); Sakai, p. 432 (partim).

Material. Extant examples include NHMW 21941 (Fig. 3E, G), NHMW 23822 (Fig. 3D) and NMCR 39031 (Fig. 3F, H). Fossil material comprises a left major propodus, one left major dactylus and one right major dactylus (Fig. 5A-D) from the Aubert de la Rüe Collection (MNHN.F A27009).

Occurrence. To date, this species is known from the Indo-West Pacific (Mataiva, Tuamotu Archipelago; Mauritius; Ternate, Indonesia; Fiji; Djibouti, Gulf of Aden; see Sakai 2005). Glypturus motupore, here considered a junior synonym of G. armatus, was recorded from Papua New Guinea (Poore and Suchanek 1988). The species is also known from the fossil record. Abrard (1947) recorded an isolated propodus and two dactyli (Fig. 5) from the Pliocene of Vanuatu.

Diagnosis. See Sakai (2005, p. 137).

Remarks. Chelipeds virtually lack tuberculation; however, larger-sized specimens usually have some tubercles at least on the merus and ischium. The lateral surfaces of the propodus usually are smooth (Fig. 4A). The merus is comparatively longer than in other extant species; therefore, it appears to be relatively slender. The meral keel usually is very weakly developed (Fig. 3D, G-H).

In their description of G. motupore, Poore and Suchanek (1988) stated that their new species lacked tuberculation on the chelipeds, thus being closely similar to G. armatus. When strictly applying criteria for the distinction of species of Glypturus, as presented here, the two can be considered synonymous. Actually, Sakai (2011) has recently synonymized G. motupore with G. armatus on the basis of softpart morphology. However, contrary to Sakai (1999, 2005, 2011), we treat G. laurae as a distinct species.

\section{Glypturus laurae (de Saint Laurent in de Vaugelas and de Saint Laurent, 1984) \\ Figures 3J, 4B}

*1984 Callichirus laurae de Saint Laurent in de Vaugelas and de Saint Laurent, p. 147, pl. 1, fig. A-D.

1988 Callichirus laurae de Saint Laurent in de Vaugelas and de Saint Laurent; Abu-Hilal et al., p. 234.
1988 Glypturus laurae (de Saint Laurent in de Vaugelas and de Saint Laurent); Poore and Suchanek, p. 201, fig. $4 \mathrm{c}$.

1991 Glypturus laurae (de Saint Laurent in de Vaugelas and de Saint Laurent); Manning and Felder, p. 778.

1999 Glypturus armatus (A. Milne-Edwards); Sakai, p. 76 (partim).

2000 Glypturus laurae (de Saint Laurent in de Vaugelas and de Saint Laurent); Tudge et al., p. 144.

2005 Glypturus armatus (A. Milne-Edwards); Sakai, p. 137 (partim).

2011 Glypturus armatus (A. Milne-Edwards); Sakai, p. 432 (partim).

Material. NHMW 6973 (Fig. 3J).

Occurrence. This species is known from the Red Sea (Gulf of Aqaba) (Dworschak 1992). Farrow (1971) and Braithwaite and Talbot (1972) described burrows attributed to Callianassa sp. from Aldabra and the Seychelles, respectively. Dworschak and Ott (1993, p. 287) stated that these were most probably made by G. laurae. No fossil material of $G$. laurae has been recorded so far.

Diagnosis. See de Vaugelas and de Saint Laurent (1984, p. 147).

Remarks. According to Dworschak (1992), this species is very close to G. acanthochirus. However, it can be distinguished by the faint tuberculation of the outer lateral surface of the propodus (Fig. 4B), as opposed to the prominent tubercules in G. acanthochirus (Fig. 4C). The sole specimen that we have examined ourselves (NHMW 6973) has few tubercles on the inner surface of the propodus extending almost vertically (Fig. 4B).

\section{Glypturus sp.}

1979 Callianassa (Callichirus) acanthochirus (Stimpson); Heard and Reames, p. 52.

1981 Callianassa acanthochirus (Stimpson); Rabalais et al., p. 103 , fig. 3 .

2005 Glypturus rabalaisae Sakai, p. 135 (name unavailable).

2007 Glypturus rabalaisae Sakai; Dworschak, p. 159 (nomen nudum).

2009 Glypturus sp. Felder et al., pp. 1062, 1093.

2011 Glypturus rabalaisae Sakai; Sakai, p. 438 (name unavailable).

Material. None.

Occurrence. This form is known solely from the northern part of the Gulf of Mexico (Felder et al. 2009).

Remarks. Rabalais et al. (1981) described several specimens as Glypturus acanthochirus. Sakai (2005) recognized them as members of a separate taxon which he named 
G. rabalaisae. However, he failed to designate a type specimen, which is why the name is unavailable, as pointed out by Dworschak (2007). Later, Sakai (2011) did select a holotype for the species, but failed to indicate its repository. As such, the specific epithet still is unavailable. Felder et al. (2009) listed this species as 'Glypturus sp'.

Rabalais et al. (1981, p. 103) did not describe the tuberculation on the lateral surfaces of the propodus in detail, but did mention the presence of 'two reduced spines on the submedian mesial surface of the merus of the major cheliped rather than with three large spines on the dorsal margin'.

\section{FOSSIL SPECIES}

\section{Glypturus berryi (Rathbun, 1935) comb. nov. Figures $4 \mathrm{E}, 6 \mathrm{~A}-\mathrm{E}$}

${ }^{\star} 1935$ Callianassa berryi Rathbun, p. 96, pl. 21, figs 12-14. 1969 Callianassa berryi Rathbun; Vía Boada, p. 40. 2010 Callianassa berryi Rathbun; Schweitzer et al., p. 34.

Material. KGP-MH HC001, a cast of the holotype (USNM MO 495112), a fragmentary left propodus of the major cheliped (Fig. 6A-E). For measurements, see Rathbun (1935, p. 97).

Occurrence. The holotype, and sole specimen known, comes from the Glendon Limestone (Vicksburg Group) of Oligocene age at Vicksburg (Warren County), Mississippi (Rathbun 1935).

Diagnosis. Strongly tuberculate Glypturus; lateral tuberculation on the propodus limited to the lower two-fifths of the outer surface and lower two-thirds of the inner surface.

Description. A detailed description of the type was provided by Rathbun (1935, p. 96), to whom reference is made.

Remarks. Rathbun (1935) pointed out that the great roughness of both inner and outer surfaces, the presence of two strong spines on the upper margin and a row of obliquely placed sockets along the inner surface of the lower margin distinguished this species from similarly shaped forms. In view of the fact that the distal margin of the specimen is damaged (Fig. 6A, C), it is feasible that there originally was a third spine at the very distal end of the upper margin of the propodus. All these characters clearly indicate this species to be a member of Glypturus, to which it is here transferred.

The nature of the tuberculation in the present species (Fig. 4E) was indicated by Rathbun (1935, p. 96) to be, 'outer surface much more convex than the inner, its lower two-fifths covered with large, separated granules or round sockets. (...) The inner surface has a depression on its lower distal portion. The lower two-thirds of this surface is covered with coarse granules like those on the outer surface.' Such tubercle arrangement is similar to that in G. munieri comb. nov. (Fig. 4D) from the Miocene of the Central Paratethys and Mediterranean and in G. fraasi comb. nov. (Fig. 4F) from the Eocene of Europe and Africa. Unfortunately, Rathbun (1935) had only a single fragmentary right propodus at her disposal, precluding determination of intraspecific variation.

Glypturus fraasi (Noetling, 1885) comb. nov. Figures $4 \mathrm{~F}, 7 \mathrm{~A}-\mathrm{C}$

*1885 Callianassa Fraasi Noetling, p. 492, pl. 4, figs 4-6.

1897 Calianassa $[$ sic] cf. Fraasi Noetling; Lörenthey, pp. 102, 114.

1898c Calianassa [sic] cf. Fraasi Noetling; Lörenthey, p. 74, pl. 5 , fig. 4 .

?1926 Callianassa cfr. Fraasi Noetling; Böhm, p. 74.

1929 Calianassa [sic] pseudo-Fraasi Lörenthey in Lörenthey and Beurlen, p. 55, pl. 1, fig. 12.

1929 Calianassa [sic] Fraasi Noetling; Lörenthey in Lörenthey and Beurlen, p. 55.

?1929 Callianassa cf. Fraasi Noetling; Glaessner: 81.

1929 Callianassa Fraasi Noetling; Glaessner: 81.

1929 Callianassa pseudofraasi Lörenthey in Lörenthey and Beurlen; Glaessner, p. 88.

1930 Callianassa Fraasi Noetling; Cuvillier, p. 276.

1959 Callianassa fraasi Noetling; Vía Boada, p. 356.

1961 Callianassa Fraasi Noetling; Farrés Mallian, p. 62.

1969 Callianassa fraasi Noetling; Vía Boada, p. 34, text-fig. 1; pl. 1, figs 1-8.

1969 Callianassa pseudo-fraasi Lörenthey in Lörenthey and Beurlen; Vía Boada, p. 40.

1970 Callianassa fraasi Noetling; Vía Boada, p. 12.

?1981 Callianassa cf. fraasi Noetling; Kensley, p. 14.

1991 Callianassa pseudofraasi Lörenthey in Lörenthey and Beurlen; Müller and Collins, p. 49.

2003 Callianassa fraasi Noetling; Serra Kiel et al., p. 211.

2010 Callianassa fraasi Noetling; Schweitzer et al., p. 35.

2010 Callianassa pseudofraasi Lörenthey in Lörenthey and Beurlen; Schweitzer et al., p. 36.

Material. The holotype of Callianassa pseudofraasi Lörenthey in Lórenthey and Beurlen, 1929 is E 9257; this is the left propodus of the major cheliped (Fig. 7A-C), the manus of which measures 21.7 and $20 \mathrm{~mm}$, in maximum length and height, respectively.

The type material of Callianassa fraasi comprises several propodi of fragmentary nature deposited under numbers MB.A 1571-1573 corresponding to published figures in Noetling (1885, pl. 4, figs 7, 5, and 6, respectively). This material was studied only through photographs provided by Christian Neumann.

Occurrence. As understood here, this species has been recorded from the Eocene of Egypt, Spain, Hungary and, possibly, 

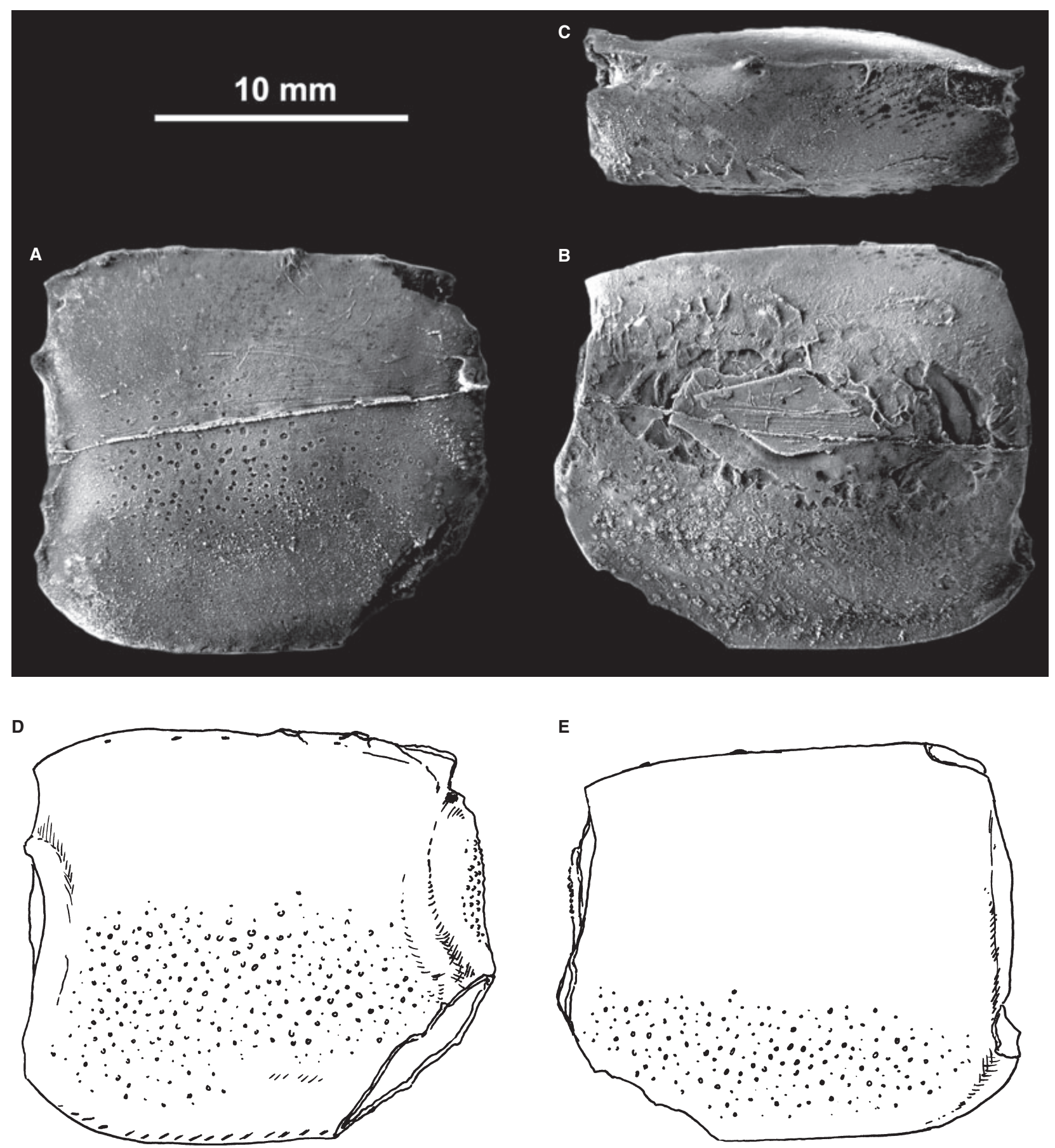

FIG. 6. Glypturus berryi (Rathbun, 1935) comb. nov. A-C, Left major propodus in inner, outer and upper views, respectively, Oligocene, Mississippi, USA (KGP-MH HC001, a cast of the holotype USNM MO 495112). D-E, interpretive drawings of A and B, respectively; note the broken propodal spines.

Namibia. The original record is from the upper Eocene of Egypt (Noetling 1885; see also Cuvillier 1930). Lörenthey (1897, 1898c) described a single specimen, as Callianassa pseudofraasi, from the upper Eocene of Hungary. Vía Boada (1959, 1969, 1970), Farrés Mallian (1961) and Serra Kiel et al. (2003) have subsequently noted this species from the middle Eocene of Spain.
Böhm (1926) described, under the name of Callianassa cf. fraasi, callianassid remains from the Eocene of Bogenfels (south-west Africa, nowadays Namibia), but failed to illustrate these. In view of the great distance separating this record from the EuropeanNorth African occurrences, we hesitate to consider this conspecific with $G$. fraasi comb. nov. 

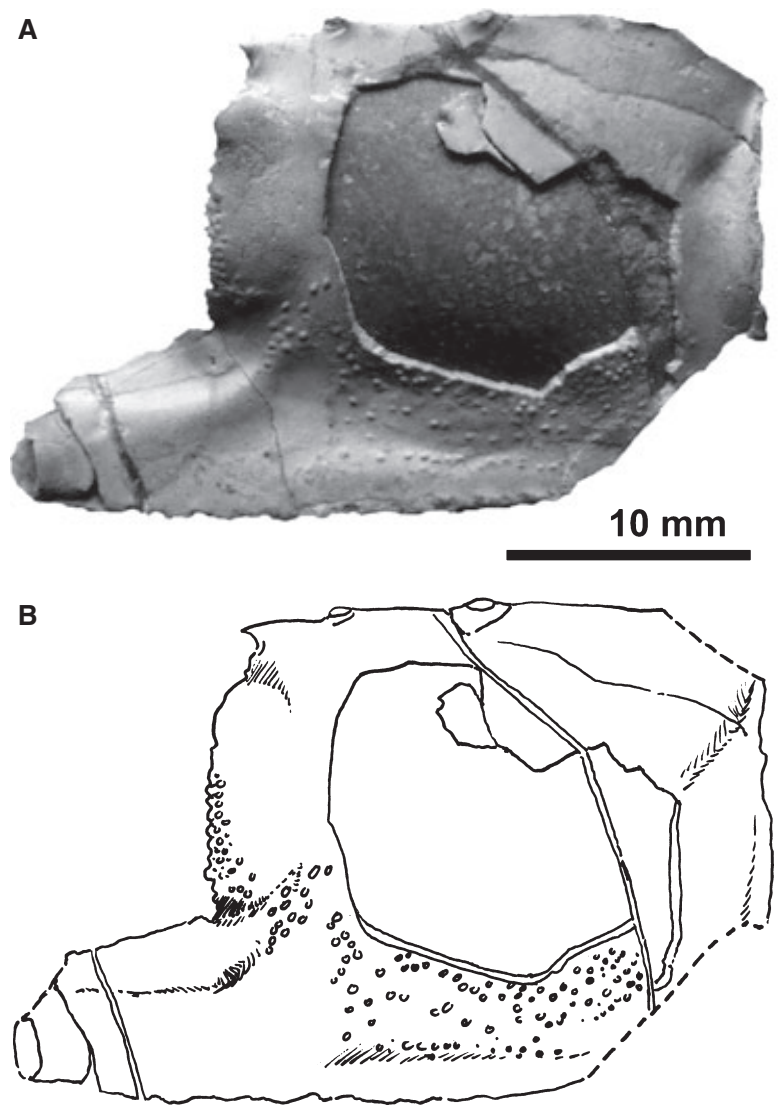

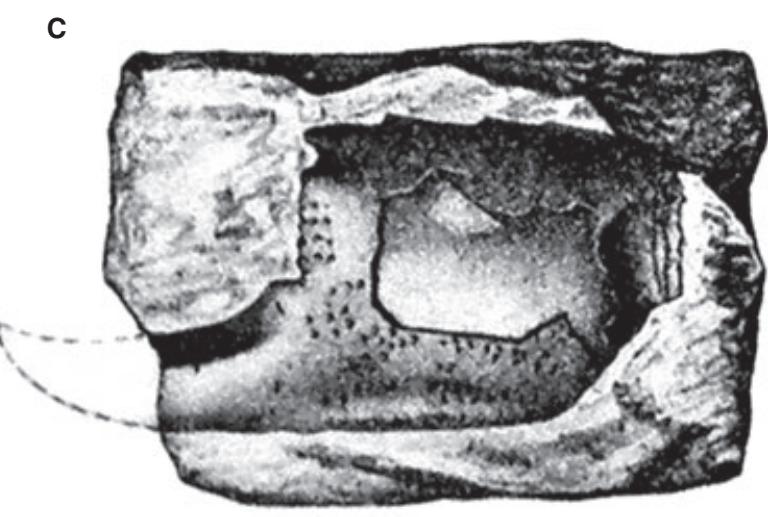

D

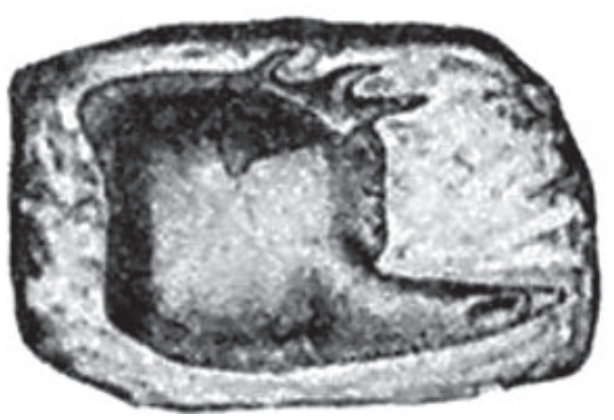

FIG. 7. Species of Glypturus from the Eocene of Hungary. A-B, Right major propodus (inner view) of Glypturus fraasi (Noetling, 1885) comb. nov., the holotype (E 9257) of Calianassa [sic] pseudofraasi Lörenthey in Lörenthey and Beurlen, 1929. C, Calianassa [sic] pseudofraasi, digital copy of Lörenthey and Beurlen (1929, pl. 1, fig. 12). D, Glypturus spinosus (Lörenthey, 1897) comb. nov., digital copy of Lörenthey \& Beurlen (1929, pl. 1, fig. 14).

Diagnosis. Strongly tuberculate Glypturus; lateral tuberculation on the propodus confined to the lower two-fifths of the outer surface and nearly the entire inner surface.

Description. A detailed description of this species was provided by Vía Boada (1969, p. 37), to whom reference is made.

Remarks. Lörenthey (1897, 1898c) described a single specimen as Calianassa [sic] cf. Fraasi from the upper Eocene near Budapest, Hungary. Later, he (Lörenthey in Lórenthey and Beurlen 1929) reassigned this to a new species, Calianassa $[s i c]$ pseudo-Fraasi, on the basis of cheliped size, arguing also that that form had two spines on the upper margin of the propodus, rather than three in C. fraasi. However, our re-examination of the holotype has revealed that in fact there are three spines. The extent of tuberculation, although poorly preserved, seems to correspond that of C. fraasi. Therefore, we consider C. pseudofraasi to be as junior synonym of $C$. fraasi. The stratigraphical distribution of the latter supports such a conclusion.
Spination and tuberculation, together with overall propodus morphology, clearly favour assignment to Glypturus. Propodal tuberculation on the propodus has the widest extension of all species discussed herein (Fig. 4F). Tubercles cover nearly the lower two-fifths of the outer surface and extend also to the lower distal corner, as they do in G. berryi comb. nov (Fig. 4E). The inner surface is nearly completely covered with tubercles, while the lower and upper margins are bare.

It may be worth mentioning that the only published figure of C. pseudofraasi (reillustrated here as Fig. 7C) does not really fit the ratios of the actual specimen. The inaccurate nature of some of the illustrations published by Lórenthey and Beurlen (1929) has previously been noted by Müller (1984a, p. 32).

Glypturus munieri (Brocchi, 1883) comb. nov.

Figures $4 D, 8 A-J, 9 A-M$

${ }^{\star} 1883$ Callianassa munieri Brocchi, p. 5, pl. 5, figs 5-6. 
1893 Calianassa [sic] Munieri Brocchi; Bittner, p. 10.

1897 Calianassa [sic] Munieri Brocchi; Lörenthey, pp. 150,160 .

1898a Calianassa [sic] Munieri Brocchi; Lörenthey, pp. 93, $105,114$.

$1898 b$ Calianassa [sic] Munieri Brocchi; Lörenthey, pp. 105, 132, 155.

1898 c Calianassa [sic] Munieri Brocchi; Lörenthey, p. 104.

1904a Calianassa [sic] Munieri Brocchi; Lörenthey, p. 161.

$1904 b$ Calianassa [sic] Munieri Brocchi; Lörenthey, p. 30.

1911 Calianassa [sic] Munieri Brocchi; Lörenthey, p. 522.

1913 Calianassa [sic] Munieri Brocchi; Lörenthey, p. 322.

1929 Callianassa Munieri Brocchi; Glaessner, p. 86.

1929 Calianassa [sic] Munieri Brocchi; Lörenthey in Lörenthey and Beurlen, pp. 33, 62-64, pl. 2, figs 19-23 (non fig. 24).

1929 Portunus rákosensis Lörenthey (partim) in Lörenthey and Beurlen, p. 173, pl. 12, figs 22-23.

?1953 Callianassa spec. ind.; Bachmayer, p. 242.

1969 Callianassa munieri Brocchi; Vía Boada, p. 40.
1975 Callianassa munieri Brocchi; Müller, p. 507.

1979 Callianassa munieri Brocchi; Müller, p. 274.

1984a Callianassa munieri Brocchi; Müller, p. 50, pl. 1, figs 1-7; pl. 2, figs 1-2.

$1984 b$ Callianassa munieri Brocchi; Müller, pl. 2, fig. 6.

1990 Callianassa munieri Brocchi; Moissette and Müller, p. 739.

1993 Callianassa munieri Brocchi; Kókay and Müller, p. 43.

2010 Callianassa munieri Brocchi; Schweitzer et al., p. 36.

2010 Callianassa munieri Brocchi; Gatt and De Angeli, p. 1324, pl. 2, figs 1-2.

Material. All materials studied represent elements (often fragmentary) of major chelipeds and are from the following localities in Austria: Baden-Sooss (NHMW 2012/0010/0001; one right propodus, Fig. 8I); Wagna bei Aflenz (NHMW 2012/0008/0001, one right propodus, Fig. 8A-B) and Pöls (NHMW 1861/0001/ 0325, one left merus articulated with carpus; NHMW 2012/0009/0001, one right propodus, Fig. 8C). Material from
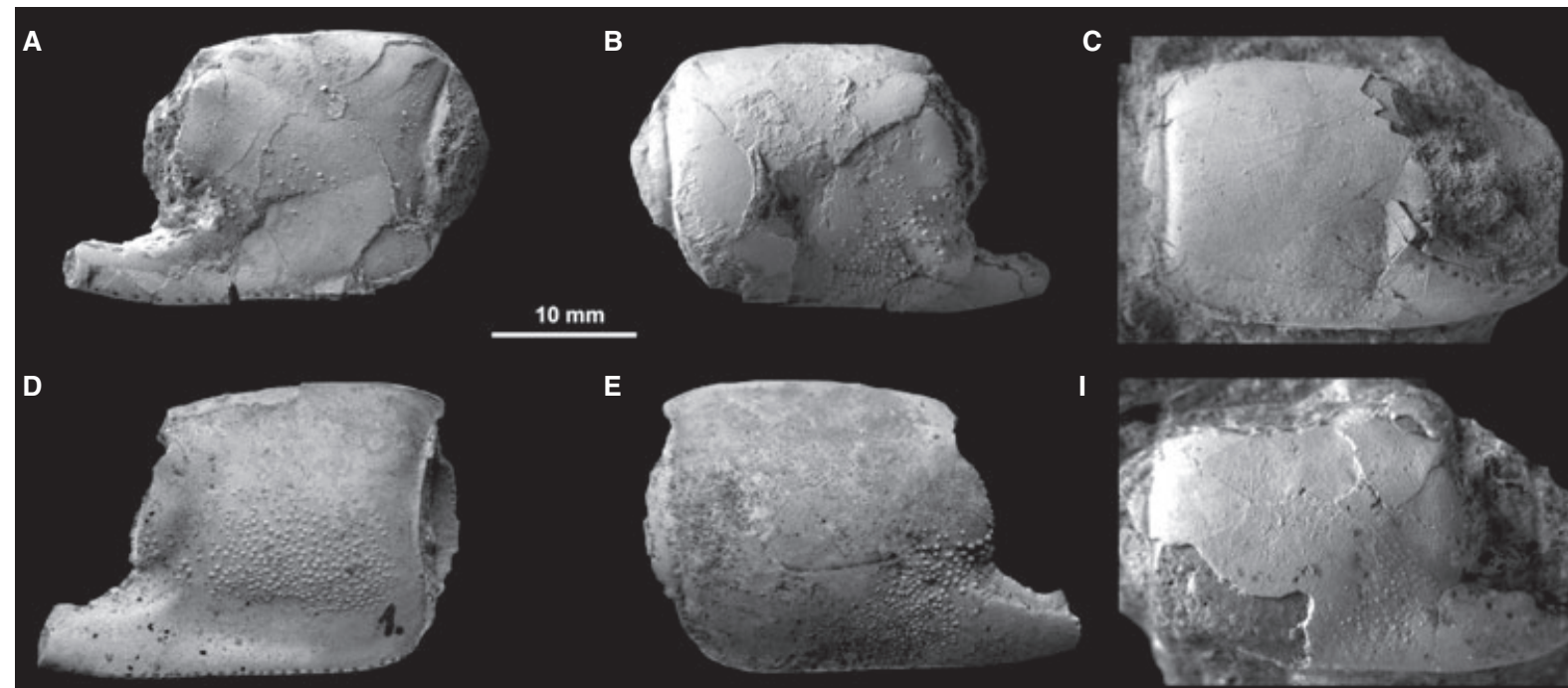

E

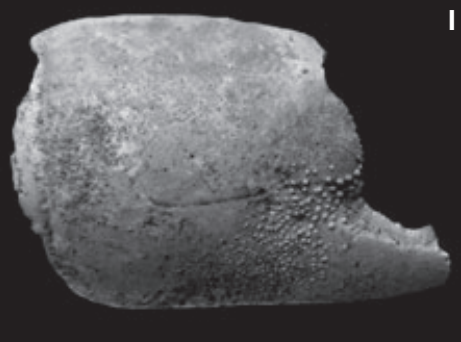

I

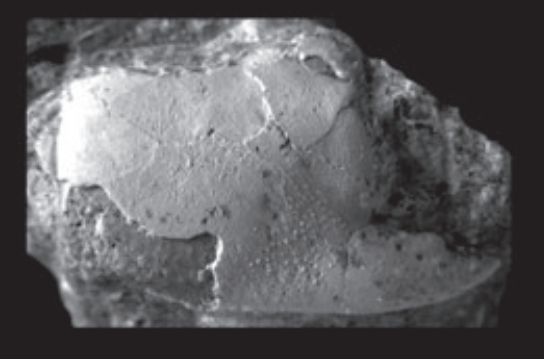

$\mathbf{F}$

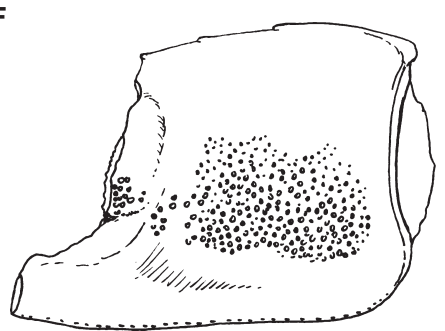

G

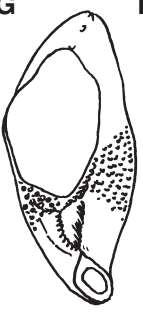

H

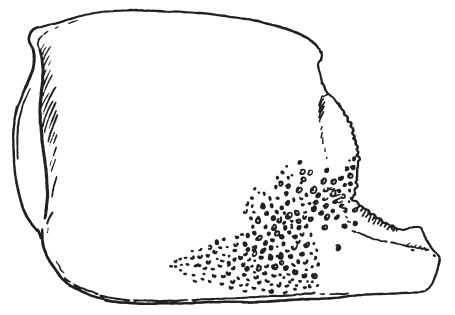

$\mathbf{J}$

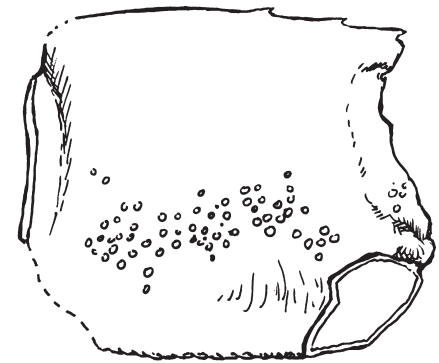

FIG. 8. Glypturus munieri (Brocchi, 1883) comb. nov. A-B, Right major propodus in inner and outer views, respectively (NHMW 2012/0008/0001), Wagna bei Aflenz, Austria. C, Right major propodus in outer view (NHMW 2012/0009/0001), Pöls, Austria. D-E, Right major propodus in inner and outer views, respectively (M.86.309), Budapest-Rákos, Hungary. F, H, Interpretive drawings of D and E, respectively. G, The same specimen in distal view. I, Right major propodus in outer view (NHMW 2012/0010/0001), BadenSooss, Austria. J, Fragmentary left major propodus in inner view (M.86.273), Budapest-Rákos, Hungary; compare extent of tuberculation with Figure 8F. At all localities, strata outcropping are of middle Miocene age. All figures to the same scale. Specimens in $\mathrm{A}-\mathrm{C}$, I were coated with ammonium chloride prior to photography. 

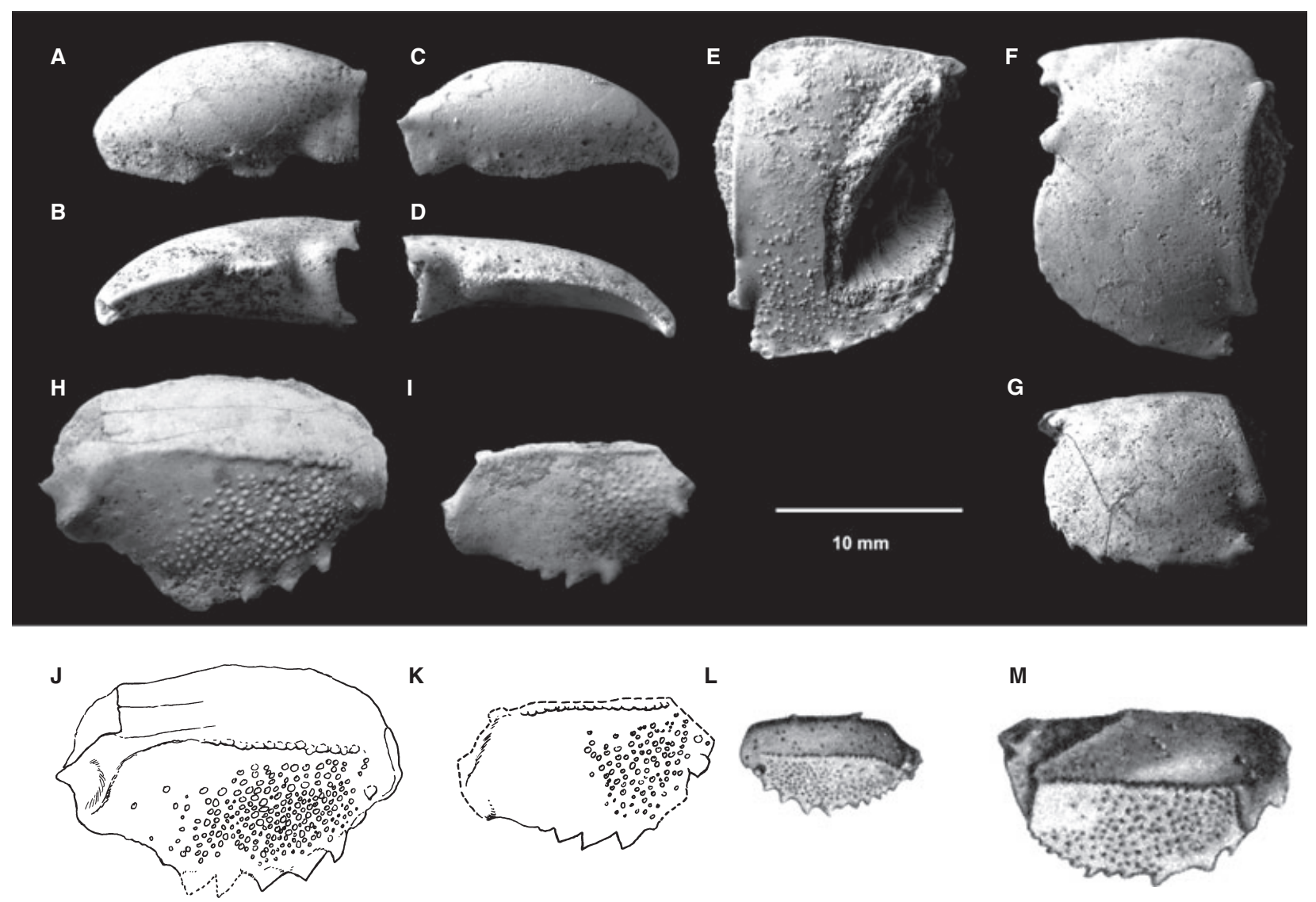

$\mathbf{L}$

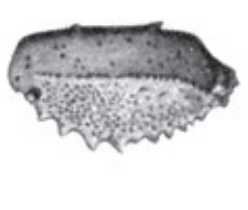

M

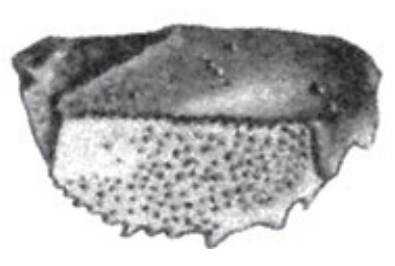

FIG. 9. Glypturus munieri (Brocchi, 1883) comb. nov. A-B, Left major dactylus in outer and occlusal views, respectively (PAL 2011.40); note broken tip. C-D, Right major dactylus in outer and occlusal views, respectively (PAL 2011.39). E-G, Right major carpus in inner, outer and oblique views, respectively (PAL 2011.38); note tuberculation on inner surface and spines on lower margin. H, Left major merus in outer view (M.86.273). I, Fragmentary left major merus in outer view (M.86.273). J-K, interpretive drawings of H and I, respectively. L-M, Right and left major merus in outer view, digital copies of Lörenthey and Beurlen (1929, pl. 12, figs 22, 23). All materials are from Budapest-Rákos (Hungary) and are of middle Miocene age. All figures to the same scale. Specimens in A-G were coated with ammonium chloride prior to photography.

localities in the Budapest area, Hungary, includes KGP-MH RA009 (one right dactylus); M.86.225 (one fragmentary left propodus); M.86.273 (two left meri, Fig. 9H-K; three right carpi, one right propodus, 1 left propodus, Fig. 8J; four left dactyli); M.86.309 (two right meri, two left carpi, one right carpus, one left propodus, seven right propodi, Fig. $8 \mathrm{D}-\mathrm{H}$; one right dactylus); M.86.393 (one left merus, one left carpus, one left propodus, one left dactylus); PAL 2011.38 (one right carpus, Fig. 9E-G); PAL 2011.39 (one right dactylus, Fig. 9C-D); PAL 2011.40 (one left dactylus, Fig. 9A-B). Specimens from Bia, Hungary, comprise M.86.460, M.86.461 and M.86.463 (all fragments of propodi).

Measurements of material are shown in Table 2.

Occurrence. This species has been recorded from the middle Miocene ('Badenian') of Hungary (Lörenthey 1897; Lörenthey and Beurlen 1929; Müller 1984a) and Austria (herein), as well as the upper Miocene (Messinian) of Malta (Gatt and De Angeli 2010).

Müller (1984a) mentioned it mainly from the upper 'Badenian' in Hungary (Budapest, Bia, Balatonakali), with but a single occurrence from lower 'Badenian' strata at Zebegény. Lörenthey (1898c) had previously noted that at Budapest-Rákos, the species was the commonest form; he had collected hundreds of specimens. All Austrian occurrences known to us are limited to deposits of early 'Badenian' age, at Pöls and Wagna bei Aflenz in the Styrian Basin and at Baden-Sooss in the Vienna Basin. Bachmayer (1953) described a single fragmentary chela from the Leitha Limestone of Deutsch-Altenburg (Austria) as Callianassa spec. ind., mentioned the presence of tubercles ('Höckerchen') and considered the specimen to be similar to C. munieri. However, he failed to provide an illustration, nor did he indicate the repository number, which is why its true nature remains unresolved.

Müller (1984a) presented details of palaeosettings and stratigraphy for localities in Hungary, while Handler et al. (2006) are referred to for a discussion of the sedimentology and stratigraphy of the section at Pöls, and Hohenegger et al. (2009) for that at Wagna bei Aflenz.

Diagnosis. Moderately tuberculate Glypturus; lateral tuberculation on the outer surface of the propodus extend- 
TABLE 2. Measurements (in $\mathrm{mm}$ ) of major cheliped elements of the best-preserved specimens of Glypturus munieri (Brocchi, 1883) comb. nov.

\begin{tabular}{|c|c|c|c|c|}
\hline Specimen & Element & Handedness & $\begin{array}{l}\text { Max. } \\
\text { length }\end{array}$ & $\begin{array}{l}\text { Max. } \\
\text { height }\end{array}$ \\
\hline M.86.273 & Merus & $\mathrm{L}$ & 17.2 & 12.0 \\
\hline M.86.273 & Merus & $\mathrm{L}$ & 13.6 & $>7.6$ \\
\hline M.86.309 & Merus & $\mathrm{R}$ & 16.3 & $>9.0$ \\
\hline M.86.309 & Merus & $\mathrm{R}$ & 13.0 & $>6.0$ \\
\hline M.86.393 & Merus & $\mathrm{L}$ & 14.0 & 7.5 \\
\hline M.86.273 & Carpus & $\mathrm{R}$ & 15.2 & 20.7 \\
\hline M.86.273 & Carpus & $\mathrm{R}$ & 14.6 & 18.3 \\
\hline M.86.273 & Carpus & $\mathrm{R}$ & 11.0 & 15.0 \\
\hline M.86.309 & Carpus & $\mathrm{L}$ & $>10.4$ & 16.4 \\
\hline M.86.309 & Carpus & $\mathrm{L}$ & 12.0 & 17.4 \\
\hline M.86.309 & Carpus & $\mathrm{R}$ & 7.6 & 11.7 \\
\hline M.86.393 & Carpus & $\mathrm{L}$ & 12.0 & 15.3 \\
\hline PAL 2011.38 & Carpus & $\mathrm{R}$ & 13.1 & 17.8 \\
\hline PM Rákos MN 10 & Carpus & $\mathrm{R}$ & $\sim 14$ & 18.4 \\
\hline PM Rákos MN 10 & Carpus & $\mathrm{R}$ & 10.6 & 13.4 \\
\hline NHMW 2012/0010/0001 & Propodus & $\mathrm{R}$ & 19.4 & 17.0 \\
\hline NHMW 2012/0009/0001 & Propodus & $\mathrm{R}$ & 15.0 & 15.6 \\
\hline NHMW 2012/0008/0001 & Propodus & $\mathrm{R}$ & 16.5 & 17.3 \\
\hline M.86.273 & Propodus & $\mathrm{L}$ & 24.0 & 22.4 \\
\hline M.86.273 & Propodus & $\mathrm{R}$ & 13.8 & 13.6 \\
\hline M.86.309 & Propodus & $\mathrm{R}$ & 15.5 & 15.0 \\
\hline M.86.309 & Propodus & $\mathrm{L}$ & 15.7 & 15.1 \\
\hline M.86.309 & Propodus & $\mathrm{R}$ & 21.6 & 20.5 \\
\hline M.86.309 & Propodus & $\mathrm{R}$ & 19.7 & 20.4 \\
\hline M.86.309 & Propodus & $\mathrm{R}$ & 18.3 & 18.6 \\
\hline M.86.309 & Propodus & $\mathrm{R}$ & 11.7 & 12.3 \\
\hline M.86.309 & Propodus & $\mathrm{R}$ & 10.0 & 10.7 \\
\hline M.86.309 & Propodus & $\mathrm{R}$ & 19.1 & 19.5 \\
\hline M.86.393 & Propodus & $\mathrm{L}$ & 15.6 & 15.2 \\
\hline PM MDSZ 1 & Propodus & $\mathrm{R}$ & 17.5 & 15.3 \\
\hline PM MKC-5.2 & Propodus & $\mathrm{L}$ & 17.0 & 14.7 \\
\hline PM MRW-2 & Propodus & $\mathrm{L}$ & 18.7 & 18.0 \\
\hline KGP-MH RA009 & Dactylus & $\mathrm{L}$ & 12.4 & 5.4 \\
\hline M.86.273 & Dactylus & $\mathrm{L}$ & 16.7 & 7.2 \\
\hline M.86.273 & Dactylus & $\mathrm{L}$ & 11.3 & 5.1 \\
\hline M.86.273 & Dactylus & $\mathrm{L}$ & 15.0 & 5.8 \\
\hline M.86.273 & Dactylus & $\mathrm{L}$ & 10.0 & 3.7 \\
\hline M.86.309 & Dactylus & $\mathrm{R}$ & 16.0 & 9.2 \\
\hline PAL 2011.39 & Dactylus & $\mathrm{R}$ & 15.0 & 6.4 \\
\hline PAL 2011.40 & Dactylus & $\mathrm{L}$ & $>15.3$ & 7.0 \\
\hline
\end{tabular}

Note that many specimens are deposited under collective numbers.

ing from the base of the fixed finger diagonally to the lower margin, but not to the proximal lower corner; lateral tuberculation on the inner surface of the propodus variable, usually covering the central portion of the manus and also extending proximally.

Emended description. Length of merus about two times height, narrowest at articulation with carpus, with keel extending longitudinally and dividing merus into two equal portions; lower portion covered densely with tubercles; lower margin convex with up to eight spines, upper margin straight, generally with three spines. Carpus broad, 1.5 times taller than long, shorter than merus; upper margin keeled, slightly convex, terminating distally in blunt corner; proximal margin with projection at articulation with merus; lower and proximal margins forming rounded edge with seven to 10 distinct spines pointing downwards; distal margin weakly concave, rimmed at articulation with manus. Propodus nearly square, slightly longer than high, converging distally; upper margin proximally keeled, bearing three small spines distally, keel terminating in blunt corner; lower margin sharp, inner lateral surface with row of setal pits; proximal margin convex on outer face, concave on inner; distal margin weakly convex; outer lateral surface covered with tubercles extending from base of fixed finger and continuing diagonally to lower margin, but not to proximal lower corner; tuberculation on inner surface variable, often covering central portion of manus. Fixed finger triangular with distinct blunt tooth on occlusal margin; dactylus with rounded upper margin, lower margin keeled with tooth-like elevation; occasionally high and stout.

Remarks. The similarity between Callianassa munieri and extant C. armata, that is, the spiny propodus, was already noted by Brocchi (1883, p. 6) and Lörenthey and Beurlen (1929, p. 64). Callianassa munieri is closely similar to extant species of Glypturus, being morphologically closest to $G$. acanthochirus.

As to published illustrations of Glypturus munieri comb. nov., we wish to make the following remarks. In the original description by Brocchi (1883, p. 5), an account of the morphology of the dactylus is lacking, although the illustrated specimens did retain this. The carpus and merus in Müller's monograph (1984a, pl. 1, figs 6-7) are figured upside down, and in the description of the carpus, the phrase 'carpus is decorated with a row of teeth on upper edge' in actual fact refers to the lower margin. The illustrations of meri of Portunus rakosensis by Lörenthey and Beurlen (1929, pl. 12, figs 22-23; reillustrated here as Fig. 9LM) actually represent meri of G. munieri comb. nov., as already hinted at by Müller (1984a).

In Glypturus munieri comb. nov., the tuberculation on the outer lateral surface of the propodus is very similar to that of G. acanthochirus; the inner surface of the former is often densely tuberculate, in contrast to that in the latter. The area of tuberculation on the inner surface is occasionally defined along its lower margin (Figs $8 \mathrm{D}, \mathrm{F}$ and $4 \mathrm{D}$ ); its extent is similar to that in G. berryi comb. nov. (Fig. 4E). It should be mentioned also that specimens of G. munieri comb. nov. with only few tubercles on the inner surface are known to us (Fig. 8A, J). Such individuals usually have a fainter tuberculation on the outer propodal surface. Interestingly, one specimen of Glypturus munieri comb. nov. with four propodal spines 
has been noted (M.86.309). Such variation is present also in other species of Glypturus.

Glypturus pugnax (Böhm, 1922) comb. nov.

*1922 Callianassa pugnax Böhm, p. 524, pl. 63, figs 17, 22, 24, 25.

1929 Callianassa pugnax Böhm; Glaessner, p. 88.

1969 Callianassa pugnax Böhm; Vía Boada, p. 40.

2010 Callianassa pugnax Böhm; Schweitzer et al., p. 36.

Material. None.

Occurrence. Upper Miocene of Kembang Sokkóh and Goenoeng Spolóng in the West-Progo Mountains, Java, Indonesia (Böhm 1922).

Description. Reference is made to Böhm (1922, p. 524).

Remarks. Unfortunately, the material originally described by Böhm (1922) could not be restudied by us, which is why a detailed comparison with other species recorded herein cannot be made. However, the presence of spines on the upper margin of the propodus and the tuberculate area on its lateral surface, both mentioned in the description and shown in the illustrations, strongly suggests reassignment to Glypturus.

Glypturus spinosus (Lörenthey, 1897) comb. nov. Figure 7D

non 1876 Callianassa spinosa de Tribolet, p. 294, pl. 1, fig. 1.

*1897 Calianassa [sic] spinosa Lörenthey, p. 158.

1898 Calianassa [sic] spinosa Lörenthey; Lörenthey, p. 76, pl. 5, fig. 6.

1929 Calianassa $[$ sic] spinosa Lörenthey; Lörenthey in Lórenthey and Beurlen, p. 57, pl. 1, fig. 14.

non 1929 Callianassa spinosa de Tribolet; Glaessner, p. 90.

1929 Callianassa subspinosa Glaessner, p. 91.

2010 Callianassa subspinosa Glaessner; Schweitzer et al., p. 37.

Material. None. The holotype, and sole specimen known, may be presumed lost.

Occurrence. Upper Eocene of Hungary. Calianassa [sic] spinosa Lorrenthey, 1897 came from the same horizon as C. pseudofraasi.

Description. For detailed description, reference is made to Lörenthey (1898c, p. 76) and Lörenthey in Lörenthey and Beurlen (1929, p. 57).

Remarks. Lörenthey (1897) described Calianassa [sic] spinosa on the basis of a single left propodus from the upper Eocene of Kis-Svábhegy near Budapest. Later, he (Lörenthey 1898c) provided an illustration of the specimen, and the same figure also appeared in the monograph by Lörenthey and Beurlen (1929) (reillustrated herein as Fig. 7D). The name was preoccupied by Callianassa spinosa de Tribolet, 1876 from the Lower Cretaceous of Switzerland, which is why Glaesssner (1929) renamed it as C. subspinosa. As such, it also appeared in the most recent compilation by Schweitzer et al. (2010). On the basis of the original figure (de Tribolet 1876, pl. 1, fig. 1), C. spinosa would appear to be utterly different from any species of Glypturus known to date. In fact, it might not even represent a callianassid at all.

The possible assignment of C. subspinosa to Glypturus has recently also been addressed by Beschin et al. (2005, p. 10). We follow suite and propose a new combination, Glypturus spinosus, herein. This also makes the replacement name Callianassa subspinosa Glaessner, 1929 redundant.

According to Lórenthey in Lórenthey and Beurlen (1929), there were several features that differentiated C. subspinosa (i.e. C. spinosa) from C. pseudofraasi. The most obvious was the size of the spines on the upper margin of the propodus, which were larger in C. spinosa. However, as shown earlier, spination on the upper margin of the propodus may be relatively variable. Other differences noted by Lörenthey in Lörenthey and Beurlen (1929) concern the shape of the propodus, which is actually not a very reliable character upon which to distinguish species. Lörenthey (1898c) mentioned that C. pseudofraasi had a tuberculate propodus, whereas Lörenthey in Lörenthey and Beurlen (1929, p. 57) stated that the lateral surface of C. subspinosa (i.e. spinosa) was completely smooth. This may be related to the fact that the size of the specimen as C. subspinosa (i.e. spinosa) is much smaller than that of C. pseudofraasi. The former may represent a minor chela which usually lacks tuberculation (Fig. 3C); the shape of the proximal part of the keel on the upper margin would argue for that (compare Fig. 3C). The fact that both species come from the same stratigraphical horizon at the same locality also favours their synonymization. Despite repeated searches, the holotype of Calianassa [sic] spinosa Lörenthey, 1897 in the Hungarian Geological Survey (Budapest), which houses the Lörenthey Collection, has not been traced so far; we assume it to be lost. We also hesitate to synonymize C. subspinosa with C. pseudofraasi (resulting in the combination G. fraasi comb. nov.), because a comparison would have to rely solely on a published figure (Lörenthey $1898 \mathrm{c}$, pl. 5, fig. 6; see also Lőrenthey and Beurlen 1929, pl. 1, fig. 14; reillustrated herein as Fig. 7D) which may not be a correct rendition of the actual specimen (see e.g. C. pseudofraasi). We must await the discovery of new material to determine the relationship between these two species.

Hojnos (1923, 1933) described Callianassa [sic] spinosa var. cserhática from 'Badenian' (middle Miocene) strata 
between the northern parts of the Cserhát and the Mátra Mountains. Unfortunately, the exact position of the locality is unknown although, as noted by Müller (1984a), it could actually refer to a small quarry in the valley of the Kis-Zagyva Creek near Mátraverebély-Szentkút. According to Müller (1984a), the material was lost, and the short description (without any figure) does not allow further conclusions. Interestingly, C. spinosa was originally described from upper Eocene strata, and it is therefore not very likely that Hojnos's material could be conspecific. More plausibly, it might represent G. munieri comb. nov., a common species at numerous localities with middle Miocene strata in Hungary and Austria.

\section{Glypturus toulai (Rathbun, 1919) \\ Figure 10A-D}

1911 'Krabbenscheren' Toula, p. 512 (26), pl. 30(1), fig. 14.

*1919 Callianassa toulai Rathbun, p. 146.

1929 Callianassa toulai Rathbun; Glaessner, p. 92.

2005 Glypturus toulai (Rathbun); Collins and Todd in Todd and Collins, p. 63, pl. 1, fig. 1.

2009 Glypturus toulai (Rathbun); Collins et al., pp. 70-71.
2010 Glypturus toulai (Rathbun); Schweitzer et al., p. 38.

Material. None.

Occurrence. Upper Miocene (Gatun Formation) of the Panama Canal (see Todd and Collins 2005).

Description. For a description, reference is made to Todd and Collins (2005, p. 63).

Remarks. Toula (1911) described two chelae from the Miocene of Panama merely as 'Krabbenscheren', illustrating one left major propodus, articulated with a dactylus. Later, Rathbun (1919) erected a new species to accommodate this, Callianassa toulai. However, in view of the fact that she failed to select a holotype, Todd and Collins (2005) designated the chela illustrated by Toula (1911, pl. 30(1), fig. 14), lectotype, although they did not re-examine the actual specimen (J. A. Todd, pers. comm. 2010). Todd and Collins (2005) also transferred the species to Glypturus on the basis of the presence of three spines on the upper margin of the propodus. In addition, they illustrated one recently collected specimen from both sides (pl. 1, fig. 1; reillustrated herein as Fig. 10).
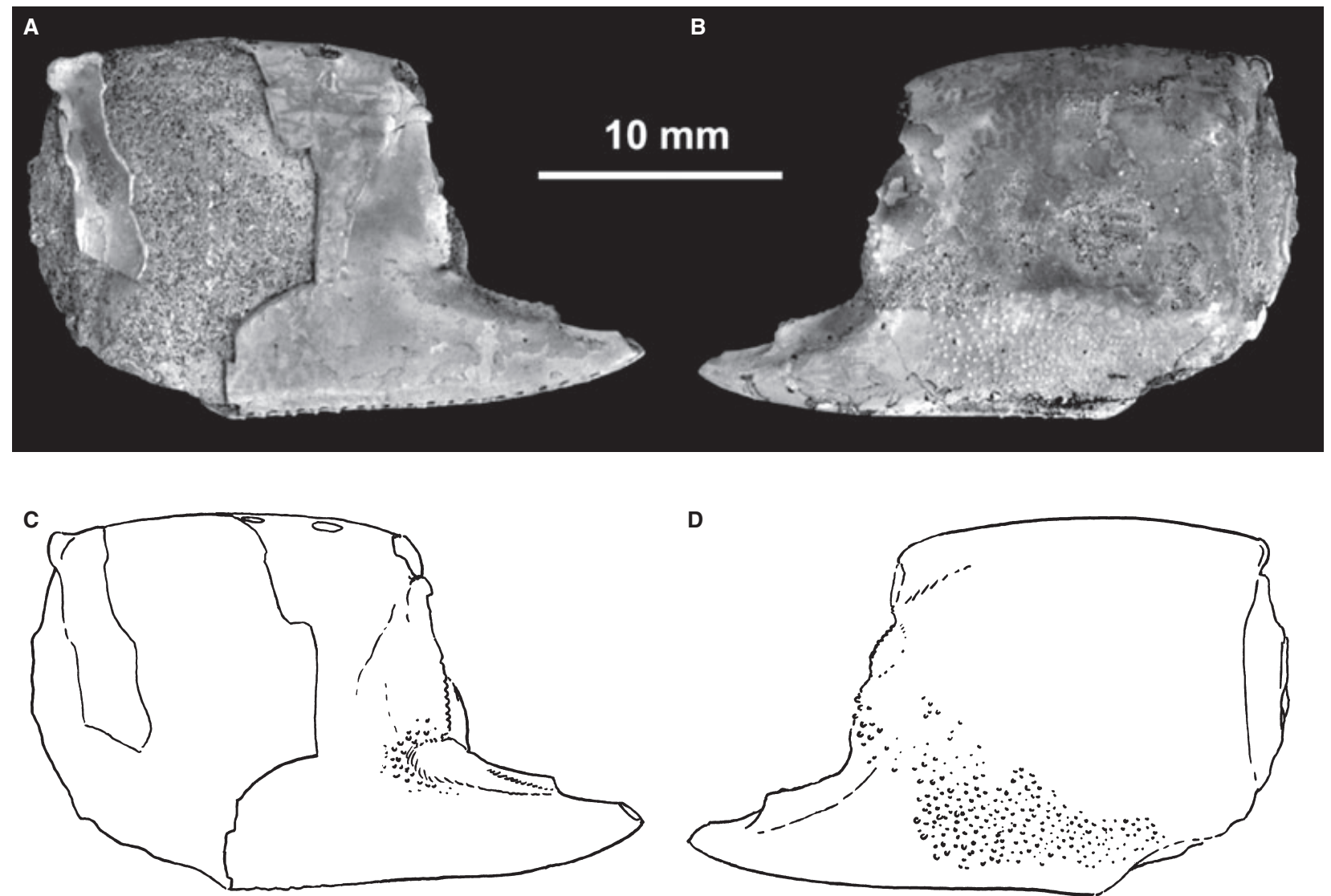

FIG. 10. Glypturus toulai (Rathbun, 1919) comb. nov. A-B, Left major propodus in inner and outer views, respectively (BMNPH PI IC 395), upper Miocene, Panama (reillustrated from Todd and Collins 2005, pl. 1, fig. 1a-b). 
According to Todd and Collins (2005), there are fewer but coarser tubercles on the lateral surface of the propodus in G. toulai than in G. acanthochirus. They argued that the extent of tubercles on the latter is a variable feature and pointed out that G. toulai may in future be found to be synonymous with G. acanthochirus. Indeed, the tuberculation on the outer surface is very similar in both species. However, it seems that tubercles on the inner surface of the propodus in G. toulai are rather different from those usually present in G. acanthochirus (but see Fig. 1B), being limited to a small area at the base of the fixed finger (Fig. 10C). To determine the intraspecific variation of $G$. toulai, more material is needed.

Genus EOGLYPTURUS Beschin, De Angeli, Checchi and Zarantonello, 2005

Type species. Eoglypturus grolensis Beschin, De Angeli, Checchi and Zarantonello, 2005, by monotypy (Fig. 2D).

Diagnosis. Manus taller than long, robust, outer surface vaulted, upper margin with five spines; fixed finger as long as manus, occlusal margin with a tooth (after Beschin et al. 2005, p. 10).

Remarks. Here, we assign this genus to the Callichirinae on account of the presence of spines on the upper margin of the propodus and the overall shape of the propodus which is close to Glypturus. No other extant callianassid genus exhibits such spination of the propodus, consistent in all its species (Eucalliax quadracuta). As the taxonomic importance of spines has already been emphasized, we argue for a close link with Glypturus, and the subfamily Callichirinae at that (contrary to De Grave et al. 2009). The holotype, and sole known specimen, of Eoglypturus grolensis (MCZ 2381) does not preserve much of the original cuticular surface, precluding observation of any tuberculate area (Beschin et al. 2005; M. H., pers. obs. 2011).

As shown above, the number of propodal spines in Glypturus is a rather variable feature and it is questionable whether the arrangement of spines in Eoglypturus grolensis is distinct enough to constitute a sound basis for the erection of a distinct genus. So long as no other material is forthcoming, we keep Eoglypturus with Glypturus separate.

Stratigraphic range. The genus appears restricted to the middle Eocene of north-east Italy (Beschin et al. 2005).

\section{PALAEOECOLOGICAL IMPLICATIONS}

The distribution of many callianassids (and Glypturus is no exception) depends on sediment characteristics, depth, vegetation and water quality. Characteristic burrow architectures are diagnostic of species as well as suggestive of ecological adaptations (Griffis and Suchanek 1991; Dworschak and Ott 1993; Abed-Navandi and Dworschak 2005; Dworschak et al. 2006).

Members of the genus Glypturus prefer carbonate substrates of lagoons and leeward sand flats adjacent to coral reefs from the shore to depths of about $30 \mathrm{~m}$ (Manning and Felder 1991). However, Rabalais et al. (1981) also recorded this genus from much deeper settings in the Gulf of Mexico, down to depths of $91 \mathrm{~m}$, although the majority of the material collected came from shallowwater settings. Rabalais et al. (1981) considered Glypturus to be an inhabitant primarily of shallow depths (10$25 \mathrm{~m}$ ) in sandy, poorly sorted sediments.

The fossil record of Glypturus suggests similar ecological preferences during its stratigraphic range over at least 40 myr. Although records of G. fraasi comb. nov. and G. spinosus comb. nov. from the Eocene of Europe do not originate exclusively from carbonate facies (see e.g. Müller and Collins 1991; Serra Kiel et al. 2003), the Miocene occurrences appear to be typically connected with carbonate sedimentation.

Glypturus munieri comb. nov. from the middle Miocene of Hungary is found in fine homogeneous sands and is rather rare in or absent from medium- to coarsegrained calcarenites (Müller 1984a). Lörenthey (1898b) noted that this species was very abundant at BudapestRákos, occurring both in the coarse limestone and in the calcareous sandstone rich in the benthic foraminifer, Alveolina. The Rákos palaeoenvironment was interpreted as a coral patch reef on a carbonate platform (Moissette et al. 2007, fig. 7). At Baden-Sooss (Austria), G. munieri comb. nov. occurs in limestone facies as well. During the middle Miocene, the climate in the Central Paratethys Sea was subtropical to warm-temperate, as documented by numerous groups of plants and animals (e.g. Moissette et al. 2006, 2007 and references therein). The sole late Miocene (Messinian) record of the species is from coralline limestones of Malta (Gatt and De Angeli 2010).

In conclusion, it follows that extinct species Glypturus are found in settings that are typical for modern relatives, that is, tropical to subtropical, nearshore carbonates of normal salinity.

\section{Burrows and feeding strategy}

Burrow morphology of Glypturus is fairly well known, having been the subject of several studies (e.g. de Vaugelas 1984; Poore and Suchanek 1988; Dworschak and Ott 1993). At the sediment/water interface, these burrows are characterized by large mounds and funnels; avalanches of sediment can often be seen sliding from the mounds into 
the funnels. The burrows consist of a central spiralling shaft with several radiating tunnels branching off from the upper level, one of them leading to a funnel, the other to a mound; the others are blocked. Deeper side branches are often filled with coarse shell material (Dworschak and Ott 1993; Dworschak 2004).

The burrow morphology of Glypturus acanthochirus was described in detail and compared with burrows of congeners by Dworschak and Ott (1993). Curran and Martin (2003) reviewed this in the context of the fossil record. Burrows of G. laurae and G. motupore (= G. armatus) were described by de Vaugelas and de Saint-Laurent (1984) and Poore and Suchanek (1988), respectively. Abu-Hilal et al. (1988) studied the distribution of trace elements in burrows made by $G$. laurae. Curran and Martin (2003) noted that the ichnogenus Ophiomorpha Lundgren, 1891 may, at least in part, comprise burrows made by Glypturus. Although burrows of Glypturus have a highly distinct morphology, no undoubted fossil equivalents have yet been recovered.

There are several reports of presumed commensal decapod crustaceans inhabiting burrows produced by Glypturus. Dworschak et al. (2006) and Anker and Dworschak (2007) noted the laomediid shrimp Naushonia Kingsley, 1897 and the alpheid shrimp Jengalpheops Anker and Dworschak, 2007 in burrows made by G. armatus from Vietnam and the Philippines, respectively. To date, there are no records of fossil members of either family associated with Glypturus. However, this is hardly surprising, in view of the fact that such usually are of small size and only weakly calcified.

At Budapest-Rákos, portions of presumed callianassid burrows have been collected (compare Hyžný 2010, fig. 1D-F). Kókay and Müller (1993, p. 43) noted also the presence of large burrows, 'sometimes with callianassid chelae preserved within, probably belonging to their inhabitants. One of these, Callianassa munieri, was of remarkably big size.' In general, the in situ preservation of callianassid remains within burrow structures is very rare (see Hyžný 2011a for a review).

Glypturus acanthochirus has been interpreted to be a deposit feeder primarily, potentially able to exploit organic matter in surface or subsurface sediments (Griffis and Suchanek 1991; Dworschak and Ott 1993; AbedNavandi and Dworschak 2005). There are also records of G. acanthochirus and G. laurae constructing burrow chambers filled with sediment and organic fragments of varying sizes and at various stages of decomposition (Suchanek 1985; Griffis and Suchanek 1991). When feeding, species of Glypturus are able to process large volumes of sediment (e.g. de Vaugelas 1985; Poore and Suchanek 1988; Dworschak and Ott 1993; Rowden and Jones 1993). Anker and Dworschak (2007, p. 298) noted that, 'Glypturus feed on organic material that enters the funnel. Coarse particles are sorted out and stored in blind tunnels. Fine material is pumped out of the burrow by vigorous beating of the pleopods, and accumulates in the form of mounds at the surface'.

\section{GEOGRAPHICAL DISTRIBUTION OF FOSSIL AND EXTANT GLYPTURUS}

Extant species of Glypturus are restricted to shallow-water marine settings (mainly carbonate shores) in the tropics and subtropics, below latitudes of 30 degrees. Biogeographically, two distinct groups have been recognized. In the western Atlantic occur G. acanthochirus and G. sp. (= G. rabalaisae sensu Sakai, 2005), while G. armatus and G. laurae inhabit the Indo-West Pacific (Fig. 11). It should be noted that G. laurae has been recorded solely from the Gulf of Aqaba (Red Sea); this species represents the most westerly occurrence of the genus in the IndoWest Pacific. In this respect, it is worth mentioning that the Red Sea is often considered to be a distinct province on account of the great percentage of endemics (Briggs 1995).

At present, there are no species of Glypturus in the Mediterranean Sea. However, the fossil record documents that the genus had much a wider distribution in the geological past (Fig. 12), both more to the south and north of its current range. This is likely to be attributable mainly to climatic changes during the Cenozoic. In consideration of the palaeobiogeography of Glypturus, the Tethys Realm as defined and discussed by Popov (1993) and Harzhauser et al. $(2002,2007)$ turns out to be a key area. Below, we adopt the palaeobiogeographical terms proposed by Harzhauser et al. (2002, 2007, 2008) and Harzhauser and Piller (2007).

\section{Glypturus in space and time}

The oldest unequivocal member of the genus is G. fraasi comb. nov. from the middle Eocene of Spain (Vía Boada 1969) and the upper Eocene of Hungary (Lörenthey and Beurlen 1929) and Egypt (Noetling 1885). It appears that Glypturus was a common and abundant faunal element in the Tethys Realm during the Eocene. Interestingly, the genus Eoglypturus from the middle Eocene of Italy (Beschin et al. 2005) is coeval with Glypturus fraasi comb. nov. (Fig. 13). Thus the question arises whether they represent sister taxa, or whether Eoglypturus is ancestral to Glypturus, or vice versa. In any case, the conclusion can be that Glypturus is of Tethyan origin (Fig. 13). Apparently, during the Eocene, the genus migrated to North America as documented by G. berryi comb. nov. from the Oligocene of Misssissippi (Rathbun 1935). It has been 


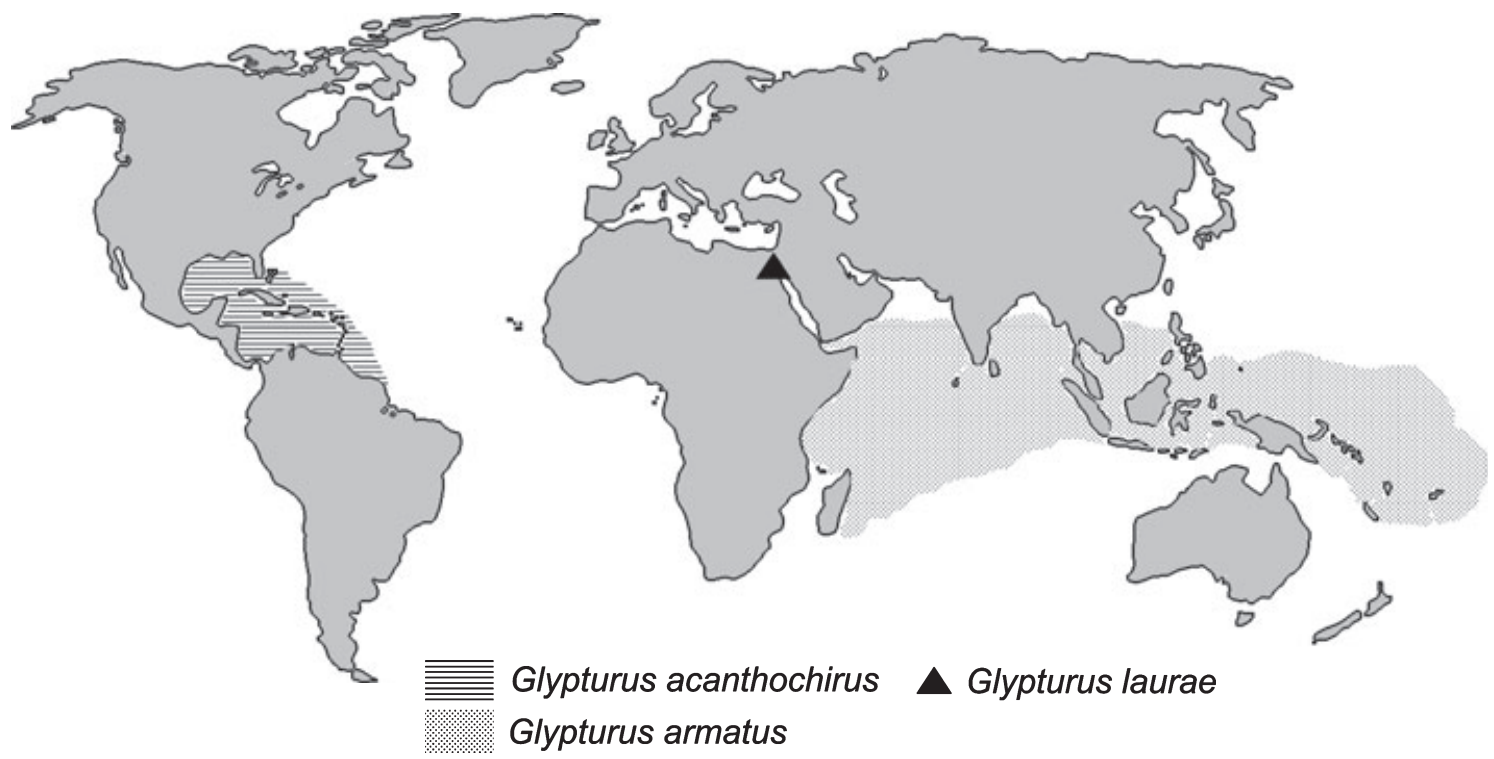

FIG. 11. Geographic distribution of extant species of Glypturus. For details, see text.

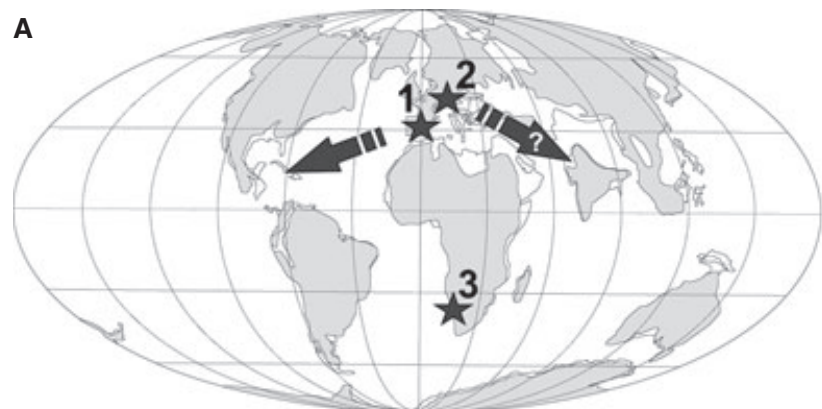

middle Eocene (Bartonian-Lutetian)

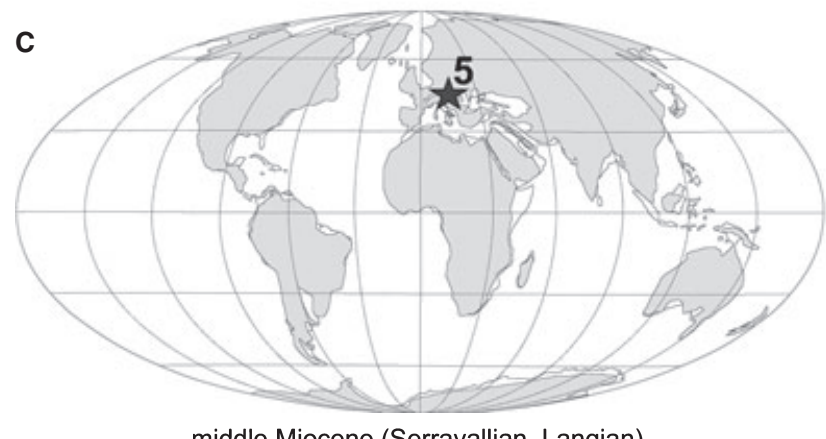

middle Miocene (Serravallian-Langian)
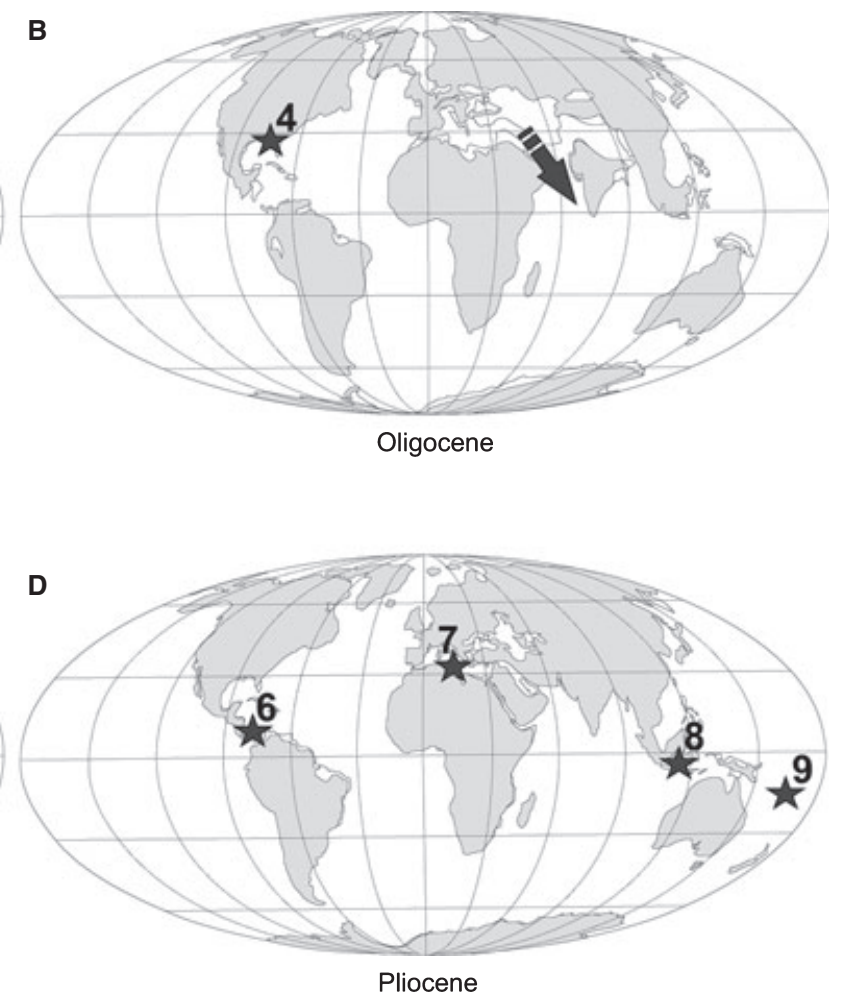

FIG. 12. Palaeobiogeography of Glypturus. A, middle Eocene (Lutetian-Bartonian). B, Oligocene. C, middle Miocene (LanghianSerravallian). D, Pliocene. 1, G. fraasi, Spain. 2, G. fraasi and G. spinosus, Hungary. 3, Callianassa cf. fraasi, Namibia. 4, G. berryi, Mississippi. 5, G. munieri, central Europe. 6, G. toulai, Panama. 7, G. munieri, Malta. 8, G. pugnax, Java. 9, G. armatus, Vanuatu. Glypturus occurrences are plotted on base maps from Smith et al. (1994). For details, see text.

shown on numerous occasions that many central American Eocene decapod crustacean taxa originated in the Tethys Realm and that migration from the Tethys to the central American bioprovinces took place during this interval (Feldmann et al. 1998; Schweitzer 2001; Schweitzer et al. 2002). 
FIG. 13. Biogeographical evolution of Glypturus. E. = Eoglypturus; G. = Glypturus. Chronostratigraphical dates are adopted from Gradstein et al. (2004). For details, see text.

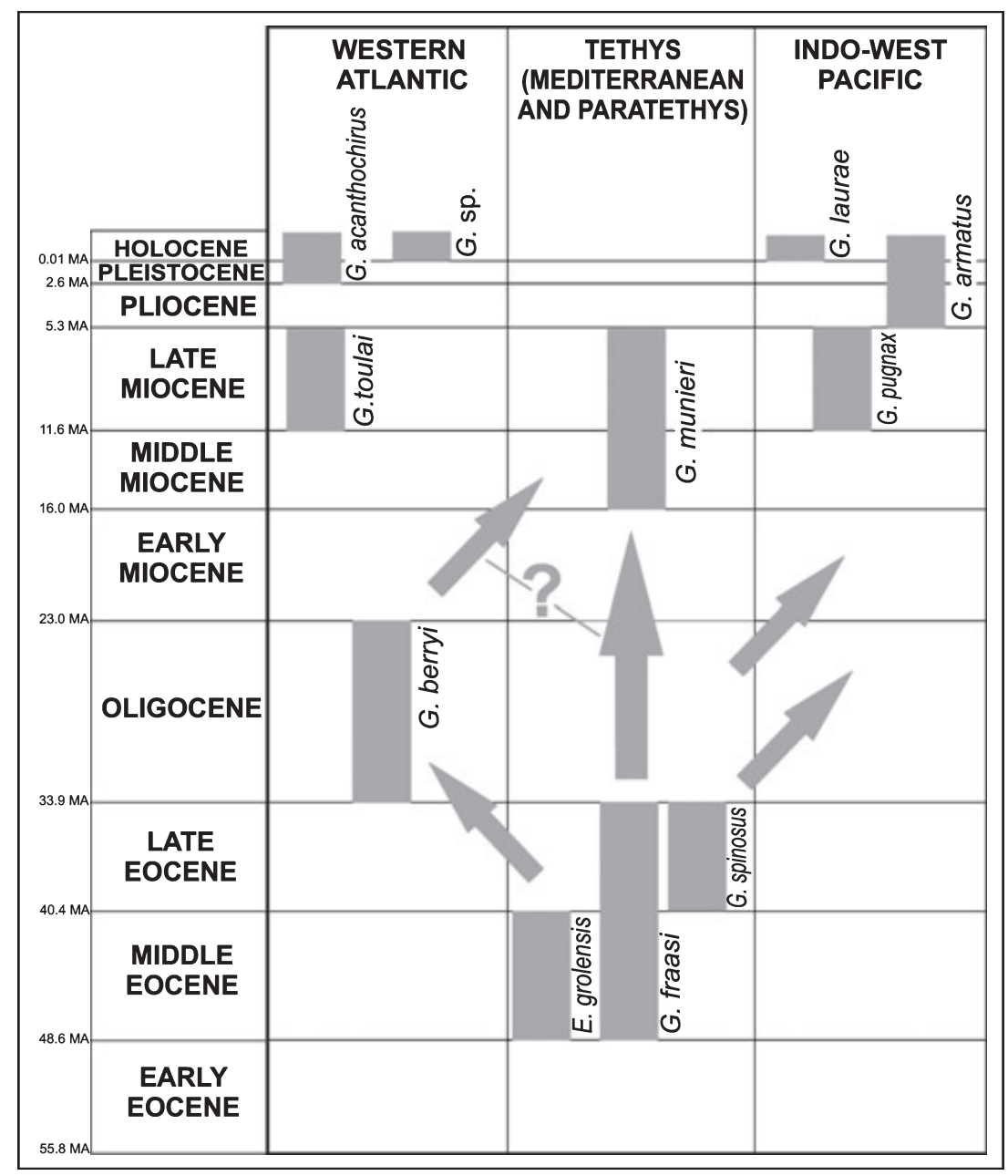

During the Oligocene, Glypturus is known only from North America (Mississippi); the absence of the genus from Europe may be explained by a global cooling event at the onset of the Oligocene (Zachos et al. 2001). However, as Feldmann (1986) observed, conclusions on decapod crustacean biogeography must be drawn on positive evidence; that is, the absence of fossils in a particular area does not necessarily mean that the taxon did not occur in that area. The presence of Glypturus (G. munieri comb. nov.) in the Miocene of the Mediterranean and central Paratethys documents either the persistence of the genus during the Oligocene or its subsequent re-introduction (Fig. 13) from North America. For gastropods (Harzhauser et al. 2002), such trans-Atlantic migrations during the early Miocene have been documented.

In the present-day Gulf of Mexico and the Caribbean Sea, the genus Glypturus occurred since its presumed immigration during the Eocene (Figs 12 and 13), with G. toulai comb. nov. in the upper Miocene of Panama (Todd and Collins 2005; Collins et al. 2009) and G. acanthochirus in the upper Pleistocene of Jamaica (Collins et al. 1996, 2009).
The presence of Glypturus munieri comb. nov. in the middle Miocene of the central Paratethys (Lörenthey and Beurlen 1929; Müller 1984a) can be linked with the middle Miocene Climate Optimum during the Langhian stage ( $\mathrm{Za}$ chos et al. 2001; Harzhauser et al. 2007). During that interval, the central Paratethys formed a distinct Danubian province within the Proto-Mediterranean-Atlantic Region (Harzhauser et al. 2002; Harzhauser and Piller 2007). Moissette et al. (2006) argued that exchange of faunas between the Mediterranean and the Paratethys was probably regulated by an anti-estuarine circulation permitting easier incursions of Proto-Mediterranean species into the Paratethys, but hindering Paratethys endemics from entering the Proto-Mediterranean. Seen in this light, G. munieri comb. nov. might be considered a Proto-Mediterranean immigrant, because it is also known from the upper Miocene of Malta. The final marine connection between the central $\mathrm{Pa}$ ratethys and Proto-Mediterranean seas was closed at the end of the middle Miocene (Serravallian). Subsequently, the central Paratethys Sea transformed into Lake Pannon, which gradually disappeared (Rögl 1998, 1999; Harzhauser and Piller 2007), which means that Glypturus must have 
gone extinct in this area. The youngest European (Tethyan) record is G. munieri comb. nov. from the upper Miocene of Malta (Gatt and De Angeli 2011). Its final disappearance from the Proto-Mediterranean-Atlantic Region at the end of the Miocene can be correlated with the Messinian Salinity Crisis, which left marine faunas of the Mediterranean basins severely impoverished (Hsü et al. 1978; Harzhauser et al. 2002; Krijgsman et al. 2010). The Messinian Salinity Crisis triggered a turnover in nearshore faunas, and although shallow-marine molluscs did recolonize the Mediterranean basins from the Atlantic (Harzhauser et al. 2002), the same cannot be postulated for Glypturus. Final transformation from the Proto-Mediterranean-Atlantic Region to the modern Mediterranean-Atlantic Region occurred during the late Pliocene and Pleistocene, influenced by distinct cooling events (Rögl and Steininger 1983). As a consequence, tropical and subtropical gastropod taxa that were present in the assemblages of the ProtoMediterranean-Atlantic Region are absent from modernday communities (Harzhauser et al. 2002), a pattern similar to the disappearance of Glypturus.

Prior to the extinction of Glypturus in the area of the modern-day Mediterranean Sea, one more dispersal event can be documented for the genus. Apart from colonization of the western Atlantic during the Paleogene, the genus apparently migrated into the Indo-West Pacific (Figs 12 and 13). Glypturus pugnax comb. nov. from Java (Böhm 1922) is of late Miocene age and its presence can be linked with the open Tethyan seaway between the Proto-Mediterranean-Atlantic and Indo-West Pacific regions during the Oligocene and early Miocene (Reuter et al. 2007). This seaway was closed at the end of the middle Miocene (Rögl 1998, 1999; Harzhauser et al. 2002, 2007; Harzhauser and Piller 2007). The fossil record suggests migration of Tethyan marine faunas in an easterly direction during the Oligo-Miocene; this led to a major shift towards the West Pacific as a centre of diversity. Such has been documented by molluscs and ophiuroids (Harzhauser et al. 2007, 2008; see also Renema et al. 2008). Apparently, decapod crustaceans of Tethyan stock took the same migratory routes (Schweitzer 2001; Hyžný 2011b). At present, species of Glypturus occur all over the Indo-West Pacific (Fig. 11).

Acknowledgements. We are most grateful to Peter C. Dworschak (Naturhistorisches Museum Wien, Vienna) for providing access to the NHMW collections of extant callianassids, extensive discussions, supply of items of literature and comments on several earlier versions of the manuscript. We also wish to thank, in alphabetical order, Antonio De Angeli (Vicenza), Alfréd Dulai (Natural History Museum, Budapest), Rodney M. Feldmann and Adiël Klompmaker (Kent State University, Ohio), Mark Florence (National Museum of Natural History, Smithsonian Institution, Washington, DC), Viviana Frisone (Museo Civico 'G. Zannato', Montecchio Maggiore), Alessandro Garassino (Museo di Storia
Naturale di Milano, Milan), Matthias Harzhauser, Oleg Mandic and Andreas Kroh (all Naturhistorisches Museum Wien, Vienna), László Kordos (Hungarian Geological Institute, Budapest), Christian Lemzaouda and Sylvain Charbonnier (Muséum national d'Histoire naturelle, Paris), Christian Neumann and Sylvain Charbonnier (Museum für Naturkunde, HumboldtUniversität, Berlin), Samuel Rybár (Comenius University, Bratislava), Jonathan A. Todd (The Natural History Museum, London) and Gerhard Wanzenböck (Bad Vöslau) for an access to collections of respective institutions, additional photographic material, literature items and helpful comments. We are grateful to R. M. Feldmann for improving the English of an earlier version of the typescript, to two anonymous reviewers for helpful suggestions and comments and to John W. M. Jagt for editorial input. This work has been supported by research grants APVV 0280-07 to D. Reháková and Comenius University Grant UK/168/2011 and PalSIRP Sepkoski Grant 2011 to M. Hyžný.

Editor. John W. M. Jagt

\section{REFERENCES}

ABED-NAVANDI, D. and DWORSCHAK, P. C. 2005. Food sources of tropical thalassinidean shrimps: a stable-isotope study. Marine Ecology Progress Series, 291, 159-168.

ABRARD, R. 1947. Fossiles néogènes et quaternaires des Nouvelles-Hébrides (Missions E. Aubert de la Rüe, 1934-1936). Annales de Paléontologie, 32, 3-113.

ABU-HILAL, A., BADRAN, M. and DE VAUGELAS, J. 1988. Distribution of trace elements in Callichirus laurae burrows and nearby sediments in the Gulf of Aqaba, Jordan (Red Sea). Marine Environmental Research, 25, 233-248.

ANKER, A. and DWORSCHAK, P. C. 2007. Jengalpheops rufus gen. nov., sp. nov., a new commensal alpheid shrimp from the Philippines (Crustacea: Decapoda). Zoological Studies, 46, 290-302.

BACHMAYER, F. 1953. Die Dekapodenfauna des tortonischen Leithakalkes von Deutsch-Altenburg (Niederösterreich). Mitteilungen der Geologischen Gesellschaft in Wien, 44 (for 1951), 237-262.

BESCHIN, C., DE ANGELI, A., CHECCHI, A. and ZARANTONELLO, G. 2005. Crostacei eocenici di Grola Presso Spagnago (Vicenza, Italia settentrionale). Studi e Ricerche, Associazione Amici del Museo, Museo Civico 'G. Zannato', Montecchio Maggiore (Vicenza), 12, 5-35.

BIFFAR, T. A. 1970. Three new species of callianassid shrimp (Decapoda, Thalassinidea) from the western Atlantic. Proceedings of the Biological Society of Washington, 83, 34-50.

— 1971. The genus Callianassa (Crustacea, Decapoda, Thalassinidea) in South Florida, with keys to the western Atlantic species. Bulletin of Marine Science, 21, 637-715.

BITTNER, A. 1893. Decapoden des pannonischen Tertiärs. Sitzungsberichte der kaiserlichen Akademie der Wissenschaften in Wien, 102, 10-37.

BÖHM, J. 1922. Crustacea. 521-538. In MARTIN, K. (ed.). Die Fossilien aus Java. Sammlung Geologischen Reichsmuseum Leiden, Neue Folge, 1/2, 538 pp. 
— 1926. Ueber tertiäre Versteinerungen von den Bogenfelser Diamantfeldern. 55-87. In KAYSER, E. (ed.). Die Diamantenwüste Südafrikas, Vol. 2. Verlag von Dietrich Reimer (Ernst Vohnsen), Berlin, 254 pp.

BORRADAILE, L. A. 1903. On the classification of the Thalassinidea. The Annals and Magazine of Natural History, series 7, 12, 534-551.

BRAITHWAITE, C. J. R. and TALBOT, M. R. 1972. Crustacean burrows in the Seychelles, Indian Ocean. Palaeogeography, Palaeoclimatology, Palaeoecology, 11, 265-285.

BRIGGS, J. C. 1995. Global biogeography (Developments in Palaeontology and Stratigraphy, 14). Elsevier, Amsterdam, 452 pp.

BROCCHI, P. 1883. Notes sur les Crustacés fossiles des terres tertiaires de la Hongrie. Annales des Sciences géologiques, 14, $1-8$.

COllins, J. S. H., DONOVAN, S. K. and DiXON, H. L. 1996. Crabs and barnacles (Crustacea: Decapoda \& Cirripedia) from the late Pleistocene Port Morant Formation of southeast Jamaica. Bulletin of the Mizunami Fossil Museum, 23, 51-63.

- PORTEll, R. W. and DONOVAN, S. K. 2009. Decapod crustaceans from the Neogene of the Caribbean: diversity, distribution and prospectus. Scripta Geologica, 138, 55-111.

COUTIÈRE, H. 1899. Note sur Callianassa grandidieri n. sp. (Voyage de M. Guillaume Grandidier à Madagascar). Bulletin du Muséum national d'Histoire naturelle Paris, 5, 285-287.

CURRAN, H. A. and MARTIN, A. J. 2003. Complex decapod burrows and ecological relationships in modern and Pleistocene intertidal carbonate environments, San Salvador Island, Bahamas. Palaeogeography, Palaeoclimatology and Palaeoeco$\log y$, 192, 229-245.

CUVILliER, J. 1930. Contribution à la paléontologie du Nummulitique Égyptien. Mémoires de l'Institut d'Égypte, Series A, 1241, 1-372.

DANA, J. D. 1852. Crustacea. Part I. United States Exploring Expedition, during the years 1838, 1839, 1840, 1841, 1842, under the command of Charles Wilkes, U.S.N., Vol. 13. C. Sherman, Philadelphia, viii +685 pp.

DE ANGELI, A. and GARASSINO, A. 2006. New reports of decapod crustaceans from the Mesozoic and Cenozoic of Friuli-Venezia Giulia (NE Italy). Atti della Società Italiana di Scienze Naturali e del Museo Civico di Storia Naturale di Milano, 147, 267-294.

DE GRAVE, S., PENTCHEFF, D. N., AHYONG, S. T., CHAN, T.-Y., CRANDALL, K. A., DWORSCHAK, P. C., FELDER, D. L., FELDMANN, R. M., FRANSEN, C. H. J. M., GOULDING, L. Y. D., LEMAITRE, R., LOW, M. E. Y., MARTIN, J. W., NG, P. K. L., SCHWEITZER, C. E., TAN, S. H., TSHUDY, D. and WETZER, R. 2009. A classification of living and fossil genera of decapod crustaceans. The Raffles Bulletin of Zoology, 21 (Suppl), 1-109.

DWORSCHAK, P. C. 1992. The Thalassinidea in the Museum of Natural History, Vienna; with some remarks on the biology of the species. Annalen des Naturhistorischen Museums in Wien, 93B, 189-238.

2000. Global diversity in the Thalassinidea (Decapoda). Journal of Crustacean Biology, 20 (Special Number 2), 238-245.

-2004. Biology of Mediterranean and Caribbean Thalassinidea. 15-22. In TAMAKI, A. (ed.). Proceedings of the Sympo- sium "Ecology of large bioturbators in tidal flats and shallow sublittoral sediments - from individual behavior to their role as ecosystem engineers". Nagasaki University, Nagasaki, 118 pp.

2005. A new species of Eucalliax Manning \& Felder, 1991 (Decapoda: Callianassidae) from the Red Sea. Proceedings of the Biological Society of Washington, 118, 209-217.

2006. A new species of Eucalliax Manning \& Felder, 1991 (Decapoda: Callianassidae) from the Philippines. The Raffles Bulletin of Zoology, 54, 349-359.

— 2007. Book review. Sakai, K. 2005: Callianassoidea of the world (Decapoda: Thalassinidea). Crustaceana Monographs 4, i-vi, 285 pp., 44 textfigs. Koninklijke Brill, NV, Leiden, The Netherlands. Journal of Crustacean Biology, 27, 158-169.

_ and OTT, J. A. 1993. Decapod burrows in mangrovechannels and back-reef environments at the Atlantic Barrier Reef, Belize. Ichnos, 2, 277-290.

- MARIN, I. and ANKER, A. 2006. A new species of Naushonia Kingsley, 1897 (Decapoda: Thalassinidea: Laomediidae) from Vietnam and the Philippines with notes on the genus Espeleonaushonia Juarrero \& Martínez-Iglesias, 1997. Zootaxa, $1372,1-16$.

FARRÉS MALLIAN, F. 1961. Enumereción de las especies halladas en del eoceno de la Comarca de Vich. Ausa, 4, 44-69.

FARROW, G. E. 1971. Back-reef and lagoonal environments of Aldabra Atoll distinguished by their crustacean burrows. Symposia of the Zoological Society, London, 28, 455-500.

FELDER, D. L. and ROBLES, R. 2009. Molecular phylogeny of the family Callianassidae based on preliminary analysis of two mitochondrial genes. 327-342. In MARTIN, J. W., CRANDALL, K. A. and FELDER, D. L. (eds). Decapod crustacean phylogenetics. Taylor \& Francis/CRC Press, Boca Raton, 632 pp.

-ÁlvareZ, F., GOY, J. W. and LEMAitre, R. 2009. 59. Decapoda (Crustacea) of the Gulf of Mexico, with Comments on the Amphionidacea. 1019-1104. In FELDER, D. L. and CAMP, D. K. (eds). Gulf of Mexico Origin, Waters, and Biota. Volume 1, Biodiversity. Texas A\&M University Press, College Station, $1312 \mathrm{pp}$.

FELDMANN, R. M. 1986. Palaeobiogeography of two decapod crustacean taxa in the Southern Hemisphere: global conclusions with sparse data. 5-19. In GORE, R. H. and HECK, K. L. (eds). Crustacean Biogeography. A. A. Balkema, Rotterdam, 292 pp.

— BICE, K. L., SCHWEITZER HOPKINS, C., SALVA, E. W. and PICKFORD, K. 1998. Decapod crustaceans from the Eocene Castle Hayne Limestone, North Carolina: paleoceanographic implications. The Paleontological Society Memoir, 48, $1-28$.

GARASSINO, A., DE ANGELI, A. and PASINI, G. 2011. A new species of ghost shrimp (Decapoda, Thalassinidea, Callianassidae) from the Late Cretaceous (Cenomanian) of Agadir (W Morocco). Atti della Società Italiana di Scienze Naturali e del Museo Civico di Storia Naturale di Milano, 152, 45-55.

GATT, M. and DE ANGELI, A. 2010. A new coral-associated decapod assemblage from the Upper Miocene (Messinian) upper coralline limestone of Malta (Central Mediterranean). Palaeontology, 53, 1315-1348.

GLAESSNER, M. F. 1929. Crustacea Decapoda. 1-464. In POMPECKJ, J. F. (ed.). Fossilium Catalogus I: Animalia, Vol. 41. W. Junk, Berlin. 
GRADSTEIN, F. M., OGG, J. G. and SMITH, A. G. 2004. A geologic time scale 2004. Cambridge University Press, Cambridge, $589 \mathrm{pp}$.

GRIFFIS, R. B. and SUCHANEK, T. H. 1991. A model of burrow architecture and trophic modes in thalassinidean shrimps (Decapoda: Thalassinidea). Marine Ecology Progress Series, 79, 171-183.

GURNEY, R. 1943. The systematics of the crustacean genus Callianassa. Proceedings of the Zoological Society of London. Series B, Systematic and Morphological, 114, 1-19.

HANDLER, R., EBNER, F., NEUBAUER, F., ANAVOICA, B. and HERMANN, S. 2006. ${ }^{40} \mathrm{Ar} /{ }^{39} \mathrm{Ar}$ dating of Miocene tuffs from the Styrian part of the Pannonian Basin: an attempt to refine the basin stratigraphy. Geologica Carpathica, 57, 483-494.

HARZHAUSER, M. and PILLER, W. E. 2007. Benchmark data of a changing sea. Palaeogeography, palaeobiogeography and events in the central Paratethys during the Miocene. Palaeogeography, Palaeoclimatology, Palaeoecology, 253, 8-31.

—— and STEININGER, F. F. 2002. Circum-Mediterranean Oligo-Miocene biogeographic evolution - the gastropods' point of view. Palaeogeography, Palaeoclimatology, Palaeoecology, 183, 103-133.

— KROH, A., MANDIC, O., PIller, W. E., GÖHLICH, U., REUTER, M. and BERNING, B. 2007. Biogeographic responses to geodynamics: a key study all around the Oligo-Miocene Tethyan Seaway. Zoologischer Anzeiger (Journal of Comparative Zoology), 246, 241-256.

- MANDiC, O., PIlleR, W. E., REUTER, M. and $\mathrm{KROH}$, A. 2008. Tracing back the origin of the Indo-Pacific mollusc fauna - basal Tridacninae from the Oligocene and Miocene of the Sultanate of Oman. Palaeontology, 51, 199213.

HEARD, R. W. and REAMES, R. C. 1979. Callianassa (Callichirus) acanthochirus (Stimpson, 1866) (Crustacea: Decapoda: Thalassinidea) from the coastal waters of Alabama. Northeast Gulf Science, 3, 51-52.

HOHENEGGER, J., RÖGL, F., ĆORIĆ, S., PERVESLER, P., LIRER, F., ROETZEL, R., SCHOLGER, R. and STINGL, K. 2009. The Styrian Basin: a key to the Middle Miocene (Badenian/Langhian) Central Paratethys transgressions. Austrian Journal of Earth Sciences, 102, 102-132.

HOJNOS, R. 1923. Adatok a Kis-Zagyva környékének földtani ismeretéhez. Bethlen Gábor Nyomda, Budapest, 8 pp.

— 1933. Über fossilen Krebsbruchteile der tuffitische Sande des Cserháts. 14-18. In HOJNOS, R. (ed.). A Mátra gazdasággeológiaijelentősége. Királyi Magyar Pázmány Péter Tudomány-egyetem Földtani Intézet, Budapest, 18 pp.

HOLMES, S. J. 1904. On some new or imperfectly known species of West American Crustacea. Proceedings of the California Academy of Sciences, series 3, 3, 307-328.

HSÜ, K. J., MONTADERT, L., BERNOUlli, D., CitA, M. B., ERICKSON, A., GARRISON, R. E., KIDD, R. B., MÉLIÈrES, F., MÜLLER, C. and WRIGHT, R. 1978. History of the Mediterranean Salinity Crisis. Initial Reports of Deep Sea Drilling Project, 42, 1053-1078.

HYŽNÝ, M. 2010. In situ mud shrimps (Decapoda: Axiidea: Callianassidae) from the middle Miocene of the Central Parat- ethys. 41-44. In GIBERT, J. M. DE, MUÑIZ, F., MAYORAL, E. and BELAÚSTEGUI, Z. (eds). Workshop on Crustacean Bioturbation - fossil and recent Abstract Volume. Lepe, Spain, May 31-June 4, 2010, 105 pp.

2011a. In situ mud shrimps (Decapoda: Axiidea: Callianassidae) preserved within their burrows from the middle Miocene of the Central Paratethys. Bulletin of the Mizunami Fossil Museum, 37, 37-46.

-2011b. Revision of Jaxea kuemeli Bachmayer, 1954 (Decapoda: Gebiidea: Laomediidae) from the Miocene of Europe, with remarks on the palaeobiogeography of the genus Jaxea Nardo, 1847. Neues Jahrbuch für Geologie und Paläontologie Abhandlungen, 260, 173-184.

— and KARASAWA, H. 2012. How to distinguish Neocallichirus, Sergio, Podocallichirus and Grynaminna (Decapoda: Callianassidae: Callichirinae) from each other in the fossil record? Bulletin of the Mizunami Fossil Museum, 38, 55-64.

— and MÜLLER, P. M. 2010. The first fossil record of the genus Callichirus (Decapoda, Axiidea, Callianassidae) from the middle Miocene of Hungary, with description of a new species. Bulletin of the Mizunami Fossil Museum, 36, 37-43.

— and SCHLÖGL, J. 2011. An Early Miocene deep-water decapod crustacean faunule from the Vienna Basin (Western Carpathians, Slovakia). Palaeontology, 54, 323-349.

KARASAWA, H. and NAKAGAWA, T. 2010. A new ghost shrimp (Decapoda: Thalassinidea) from the Miocene Kunimi Formation, Fukui Prefecture, Japan. Bulletin of the Mizunami Fossil Museum, 36, 31-36.

KENSLEY, B. 1975. Records of mud-prawns (Genus Callianassa) from South Africa and Mauritius (Crustacea, Decapoda, Thalassinidea). Annals of the South African Museum, 69, 47-57.

1981. On the zoogeography of southern African decapod Crustacea, with a distributional checklist of the species. Smithsonian Contributions to Zoology, 338, 1-64.

KINGSLEY, J. S. 1897. On a new genus and two new species of macrurous Crustacea. Bulletin of the Essex Institute, 27 (for 1895), 95-100.

- 1899. Synopsis of North-American Invertebrates. IV. Astacoid and Thalassinoid Crustacea. The American Naturalist, 33, 819-824.

KÓKAY, J. and MÜLLER, P. 1993.Budapest, Rákos railwaycut: Badenian and Sarmatian limestones with rich marine fauna, coral reef. 40-44. In 8th Meeting of the Association of European Geological Sciences. Excursion Guide, Field Trip A, Marginal facies of the Pannonian Basin, 1993. Hungarian Geological Society, Budapest, 70 pp.

KRIJGSMAN, W., STOICA, M., VASILIEV, I. and POPOV, V. V. 2010. Rise and fall of the Paratethys Sea during the Messinian Salinity Crisis. Earth and Planetary Science Letters, 290, 183-191.

LA TREILLE, P. A. 1802-1803. Histoire naturelle, générale et particulière des crustacés et des insectes. F. Dufart, Paris, 468 pp.

LEACH, W. E. 1814. Crustaceology. 385-437. In BREWSTER, D. (ed.). Edinburgh encyclopaedia 7(2). Baldwin, London, $437 \mathrm{pp}$.

LÖRENTHEY, E. 1897. Adatok Magyarország harmadkorú rák-faunájához. Mathematikai és Természettodományi Értesito, 15, 149-169. 
— 1898a. Beiträge zur Decapodenfauna des ungarischen Tertiärs. Mathematische und Naturwissenschaftliche Berichte aus Ungarn, 14, 92-115.

1898b. Adatok Magyarország harmadkorú rák-faunájához. Mathematikai és Természettudományi Közlemények, 27 (2), $103-271$.

— 1898c. Beiträge zur Decapodenfauna der ungarischen Tertiärs. Természetrajzi Füzetek, 21, 1-133.

1904a. Palaeontológiai tanulmányok a harmadkorú rákok köréból. Mathematikai és Természettodományi Értesito, 22, $160-167$.

— 1904b. Paläontologische Studien über tertiäre Decapoden. Mathematische und Naturwissenschaftliche Berichte aus Ungarn, 22, 29-34.

— 1911. Újabb adatok Budapest környéke harmadidőszaki üledékeinek geológiájához. Mathematikai és Természettodományi Értesito, 29, 515-535.

1913. Neuere Beiträge zur Stratigraphie der Tertiärbildungen in der Umgebung von Budapest. Mathematische und Naturwissenschaftliche Berichte aus Ungarn, 27, 282-394.

— and BEURLEN, K. 1929. Die fossilen Dekapoden der Länder der Ungarischen Krone. Geologica Hungarica, Series Palaeontologica, 3, 1-421.

LUNDGREN, S. A. B. 1891. Studier öfver fossilförande lösa block. Geoliska Föreningens i Stockholm Förhandlingar, 13, 111-121.

MAN, J. G. DE 1902. Die von Herrn Professor Kükenthal im Indischen Archipel gesammelten Dekapoden und Stomatopoden. Abhandlungen der Senckenbergischen Naturforschenden Gesellschaft, 25, 467-929.

- 1928. The Decapoda of the Siboga-Expedition. Part 7. The Thalassinidae and Callianassidae collected by the Siboga-Expedition with some remarks on the Laomediidae. Siboga Expeditie, 39 (A6), 1-187.

MANNING, R. B. 1987. Notes on western Atlantic Callianassidae (Crustacea: Decapoda: Thalassinidea). Proceedings of the Biological Society of Washington, 100 (2), 386-401.

- 1992. A new genus for Corallianassa xutha Manning (Crustacea: Decapoda: Callianassidae). Proceedings of the Biological Society of Washington, 105 (3), 571-574.

1993. Two new species of Neocallichirus from the Caribbean Sea (Crustacea: Decapoda: Callianassidae). Proceedings of the Biological Society of Washington, 106, 106-114.

— and FELDER, D. L. 1991. Revision of the American Callianassidae (Crustacea: Decapoda: Thalassinidea). Proceedings of the Biological Society of Washington, 104, 764-792.

— and LEMAITRE, R. 1994. Sergio, a new genus of ghost shrimp from the Americas (Crustacea: Decapoda: Callianassidae). Nauplius, 1, 39-43.

MIERS, E. J. 1884. On some Crustaceans from Mauritius. Proceedings of the Zoological Society London, 1884, 10-17.

MILNE-EDWARDS, A. 1870. Révision du genre Callianassa (Leach) et description de plusieurs espèces nouvelles de ce groupe faisant partie de la collection du muséum. Nouvelles Archives du Muséum d'Histoire naturelle Paris, 6, 75-101.

MOIssetTe, P. and MÜlleR, P. 1990. Crustacés décapodes des faciès marno-diatomitiques du Messinien d'Oranie (Algérie Occidentale). Geobios, 23, 737-747.
— DULAI, A. and MÜLLER, P. 2006. Bryozoan faunas in the Middle Miocene of Hungary: biodiversity and biogeography. Palaeogeography, Palaeoclimatology, Palaeoecology, 233, 300-314.

———escarguel, G., KÁZMÉR, M., MÜller, P. and SAINT MARTIN, J.-P. 2007. Mosaic of environments recorded by bryozoan faunas from the Middle Miocene of Hungary. Palaeogeography, Palaeoclimatology, Palaeoecology, 252, 530-556.

MÜLLER, P. 1975. Decapoda (Crustacea) fauna a budapesti miocénból (3). Földtani Közlöny, 105, 506-517.

— 1979. Decapoda (Crustacea) fauna a budapesti miocénból (5). Földtani Közlöny, 108, 272-312.

— 1984a. Decapod Crustacea of the Badenian. Geologica Hungarica, Series Palaeontologica, 42, 3-317.

- 1984b. Messinian and older decapods from the Mediterranean with description of two new species. Annales Géoologiques des Pays Helléniques, 32, 25-34.

— and COLLINS, J. S. H. 1991. Late Eocene coral-associated decapods (Crustacea) from Hungary. Contributions to Tertiary and Quaternary Geology, 28, 47-92.

NGOC-HO, N. 2005. Thalassinidea (Crustacea, Decapoda) from French Polynesia. Zoosystema, 27, 47-83.

NOETLING, F. 1885. Ueber Crustaceen aus dem Tertiär Aegyptens. Sitzungsberichte der Königlich Preussischen Akademie der Wissenschaften zu Berlin, 26, 487-500.

POORE, G. C. B. 1994. A phylogeny of the families of Thalassinidea (Crustacea: Decapoda) with keys to families and genera. Memoirs of Museum Victoria, 54, 79-120.

2000. A new genus and species of callianassid ghost shrimp from Kyushu, Japan (Decapoda: Thalassinidea). Journal of Crustacean Biology, 20 (Special Number 2), 150-156.

— and GRIFFIN, D. J. G. 1979. The Thalassinidea (Crustacea: Decapoda) of Australia. Records of the Australian Museum, 32, 217-321.

— and SUCHANEK, T. H. 1988. Glypturus motupore, a new callianassid shrimp (Crustacea: Decapoda) from Papua New Guinea with notes on its ecology. Records of the Australian Museum, 40, 197-204.

POPOV, S. V. 1993. Zoogeography of the Late Eocene basins of western Eurasia based on bivalve mollusks. Stratigraphy and Geological Correlation, 2, 103-118.

RABALAIS, N. N., HOLT, S. A. and FLINT, R. W. 1981. Mud shrimps (Crustacea, Decapoda, Thalassinidea) of the Northwestern Gulf of Mexico. Bulletin of Marine Science, 31, 96-115.

RATHBUN, M. J. 1900. Results of the Branner-Agassiz expedition to Brazil. I. The decapod and stomatopod Crustacea. Proceedings of the Washington Academy of Sciences, 2, 133-156.

- 1901. The Brachyura and Macrura of Porto Rico. Bulletin of the United States Fish Commission, 20 (for 1900), 1-127.

- 1919. West Indian Tertiary decapod crustaceans. 159-184. In VAUGHAN, T. W. (ed.). Contributions to the geology and paleontology of the West Indies. Carnegie Institution of Washington Publication, 291, 184 pp.

- 1935. Fossil Crustacea of the Atlantic and Gulf Coastal Plain. Geological Society of America Special Papers, 2, viii $+1-$ 160. 
RENEMA, W., BELLWOOD, D. R., BRAGA, J. C., BROMFIELD, K., HALL, R., JOHNSON, K. G., LUNT, P., MEYER, C. P., MCMONAGLE, L. B., MORLEY, R. J., O'REA, A., TODD, J. A., WESSELINGH, F. P., WILSON, M. E. J. and PANDOLFI, J. M. 2008. Hopping hotspots: global shifts in marine biodiversity. Science, 321, 654657.

REUTER, M., PILlER, W. E., HARZHAUSER, M., MANDIC, O., BERNING, B., RÖGL, F., KROH, A., AUBRY, M.-P., WIELANDT-SCHUSTER, U. and HAMEDANI, A. 2007. The Oligo-/Miocene Qom Formation (Iran): evidence for an early Burdigalian restriction of the Tethyan seaway and closure of its Iranian gateways. International Journal of Earth Science, 98, 627-650.

ROBLES, R., TUDGE, C. C., DWORSCHAK, P. C., POORE, G. C. B. and FELDER, D. L. 2009.Molecular phylogeny of the Thalassinidea based on nuclear and mitochondrial genes. 309-326. In MARTIN, J. W., CRANDALL, K. A. and FELDER, D. L. (eds). Decapod crustacean phylogenetics. Taylor \& Francis/CRC Press, Boca Raton, 632 pp.

RÖGL, F. 1998. Palaeogeographic considerations for Mediterranean and Paratethys seaways (Oligocene to Miocene). Annalen des Naturhistorischen Museums in Wien, 99, 279-310.

- 1999. Mediterranean and Paratethys. Facts and hypotheses of an Oligocene to Miocene paleogeography (short overview). Geologica Carpathica, 50, 339-349.

— and STEININGER, F. F. 1983. Vom Zerfall der Paratethys zu Mediterran und Paratethys. Die neogene Paläogeographie und Palinspastik des zirkum-mediterranen Raumes. Annalen des Naturhistorischen Museums in Wien, 85A, 135163.

ROWDEN, A. A. and JONES, M. B. 1993. Critical evaluation of sediment turnover estimates for Callianassidae (Decapoda: Thalassinidea). Journal of Experimental Marine Biology and Ecology, 173, 265-272.

SAINT LAURENT, M. DE 1973. Sur la systématique et la phylogénie des Thalassinidea: définition des familles des Callianassidae et des Upogebiidae et diagnose de cinq genres nouveaux (Crustacea Decapoda). Comptes Rendus hebdomadaires de Séances de l'Académie des Sciences, série D, 277, 513-516.

1979. Sur la classification et la phylogénie des Thalassinides: définitions de la superfamille des Axioidea, de la sous-famille des Thomassiniinae et de deux genres nouveaux (Crustacea Decapoda). Comptes Rendus hebdomadaires de Séances de l'Académie des Sciences, série D, 288, 1395-1397.

_ and LE LOEUFF, P. 1979. Campagnes de la Calypso au large des côtes Atlantiques Africaines (1956 et 1959) (suite) 22. Crustacés Décapodes Thalassinidea. I. Upogebiidae et Callianassidae. Résultats Scientifiques des Campagnes de la Calypso, 11, 29-101.

SAKAI, K. 1988. A new genus and five new specie of Callianassidae (Crustacea: Decapoda: Thalassinidea) from Northern Australia. The Beagle (Records of the Northern Territory Museum of Arts and Sciences), 5, 51-69.

— 1999. Synopsis of the family Callianassidae, with keys to subfamilies, genera and species, and the description of new taxa (Crustacea: Decapoda: Thalassinidea). Zoologische Verhandelingen, 326, 1-152.
- 2002. Callianassidae (Decapoda, Thalassinidea) in the Andaman Sea, Thailand. Phuket Marine Biological Center Special Publication, 23, 461-532.

- 2005. Callianassoidea of the world (Decapoda: Thalassinidea). Crustaceana Monographs, 4, 1-285.

2011. Axioidea of the World and a Reconsideration of the Callianassoidea (Decapoda, Thalassinidea, Callianassida). Crustaceana Monographs, 13, 1-520.

SCHMITT, W. L. 1935. Mud shrimps of the Atlantic coast of North America. Smithsonian Miscellaneous Contributions, 93, $1-21$.

SCHWEITZER, C. E. 2001. Paleobiogeography of Cretaceous and Tertiary decapod crustaceans of the North Pacific Ocean. Journal of Paleontology, 75, 808-826.

— and FELDMANN, R. M. 2002. New Eocene decapods (Thalassinidea and Brachyura) from southern California. Journal of Crustacean Biology, 22, 938-967.

—— GONZÁLES-BARBA, G. and VEGA, F. J. 2002. New crabs from the Eocene and Oligocene of Baja California Sur, Mexico and an assessment of the evolutionary and paleobiogeographic implications of Mexican fossil decapods. The Paleontological Society Memoir, 59, 1-43.

—_GONZÁleZ-BARBA, G., FELDMANN, R. M. and WAUGH, D. A. 2006a. Decapoda (Thalassinoidea and Paguroidea from the Eocene Bateque and Tepetate formations, Baja California Sur, México: systematics, cuticle microstructure, and paleoecology. Annals of Carnegie Museum, 74, 275-293 (imprint 2005).

- iturRalde-Vinent, M., Hetler, J. L. and VELEZ-JUARBE, J. 2006b. Oligocene and Miocene decapods (Thalassinidea and Brachyura) from the Caribbean. Annals of Carnegie Museum, 75, 111-136.

- FELDMANN, R. M., GARASSINO, A., KARASAWA, H. and SCHWEIGERT, G. 2010. Systematic list of fossil decapod crustacean species. Crustaceana Monographs, 10, 1-222.

SCHWEITZER-HOPKINS, C. and FELDMANN, R. M. 1997. Sexual dimorphism in fossil and extant species of Callianopsis de Saint Laurent. Journal of Crustacean Biology, 17, 236-252.

SERIDJI, R. 1995. On a collection of decapod larvae from the Gulf of Aqaba off the Jordanian coast, I. Thalassinidea and Anomura. Crustaceana, 68, 282-320.

SERRA KIEL, J., MATÓ, E., SAUlA, E., TRAVÉ, A., FERRANDEZ-CANADELL, C., BUSQUETS, P., SAMSÓ, J. M., TOSQUELLA, J., BARNOLAS, A., ALVAREZ-PÉREZ, G., FRANQUÈS, J. and ROMERO, J. 2003. An inventory of the marine and transitional Middle/Upper Eocene deposits of the southeastern Pyrenean Foreland Basin (NE Spain). Geologica Acta, 1, 201-229.

SMITH, A. G., SMITH, D. G. and FUNNELL, B. M. 1994. Atlas of Mesozoic and Cenozoic coastlines. Cambridge University Press, Cambridge, 99 pp.

STIMPSON, W. 1866. Descriptions of new genera and species of Macrurous Crustacea from the coasts of North America. Proceedings of the Chicago Academy of Sciences, 1, 46-48.

1871. Notes on North American Crustacea in the Museum of the Smithsonian Institution. No. III. Annals of the Lyceum of Natural History of New York, 10, 92-136. 
STRAHL, C. 1861. Über einige neue von Hrn F.Jagor eingesandte Thalassinen und die systematische Stellung dieser Familie. Monatsberichte der Königlichen Akademie der Wissenschaften zu Berlin, 1861, 1055-1072.

SUCHANEK, T. H. 1985. Thalassinid shrimp burrows: ecological significance of species-specific architecture. 205-210. In HARMELIN-VIVIEN, M., SALVAT, B. and GABRIE, C. (eds). Proceedings of the 5th International Coral Reef Congress, Papeete, Tahiti, Vol. 5. Antenne Museum-Ephe, Moorea, French Polynesia, 554 pp.

TODD, A. J. and COLLINS, J. S. H. 2005. Neogene and Quaternary crabs (Crustacea, Decapoda) collected from Costa Rica and Panama by members of the Panama Paleontology Project. Bulletin of the Mizunami Fossil Museum, 32, 53-85.

TOULA, F. 1911. Die jungtertiäre Fauna von Gatun am Panamakanal. Jahrbuch der kaiserlich-königlichen Geologischen Reichanstalt Wien, 61, 487-530.

TRIBOLET, M. DE 1876. Description de quelques espèces de Crustacés Décapodes du Valanginien, Néocomien et Urgonien de la Haute-Marne, du Jura et des Alpes. Bulletin de la Société des Sciences naturelles de Neuchâtel, 10, 868-870.

TUDGE, C. C., POORE, G. C. B. and LEMAITRE, R. 2000. Preliminary phylogenetic analysis of generic relationships within the Callianassidae and Ctenochelidae (Decapoda: Thalassinidea: Callianassoidea). Journal of Crustacean Biology, 20 (Special Issue 2), 129-149.

VAUGELAS, J. DE 1984. Preliminary observations on two types of callianassid (Crustacea, Thalassinidea) burrows. Gulf of Aqaba (Red Sea). 520-539. In SAAD, M. A. H. (ed.). Proceeding of the Symposium on Coral Reef Environments of the Red Sea. King Abdulaziz University Press, Jeddah, 681 pp.

1985. Sediment reworking by callianassid mud-shrimp in tropical lagoons: a review with perspectives. 617-620. In HARMELIN-VIVIEN, M., SALVAT, B. and GABRIE, C. (eds). Proceedings of the 5th International Coral Reef Congress, Papeete, Tahiti, Vol. 6. Antenne Museum-Ephe, Moorea, French Polynesia, 620 pp.

— and SAINT LAURENT, M. DE 1984. Premières données sur l'écologie de Callichirus laurae de Saint Laurent sp. nov. (Crustaceé Décapode Callianassidae): son action bioturbatrice sur les formations sédimentaires du golfe d'Aqaba (Mer Rouge). Comptes Rendus hebdomadaires de Séances de l'Académie des Sciences Paris, 298, 147-152.

VÍA BOADA, L. 1959. Decápodos fósiles del Eoceno español. Boletín del Instituto Geológico y Minero de España, 70, 331402.

1969. Crustacéos Decápodos del Eoceno español. Pirineos, 91-94, 1-479.

1970. Estudio paleontológico y bioestratigráfico de Montezumella amenosi, interesante braquiuro (Atelecyclidae) del Eoceno catalán. Acta Geológica Hispánica, 5, 12-18.

ZACHOS, J., PAGANI, M., SLOAN, L., ThOMAS, E. and BILLUPS, K. 2001. Trends, rhythms, and aberrations in global climate $65 \mathrm{Ma}$ to present. Science, 292, 686693. 